\title{
Electrochemical treatment of human waste coupled with molecular hydrogen production $\dagger$
}

\author{
Kangwoo Cho, ${ }^{\text {ab }}$ Daejung Kwon ${ }^{\text {ac }}$ and Michael R. Hoffmann*a
}

We have developed a wastewater treatment system that incorporates an electrolysis cell for on-site wastewater treatment coupled with molecular hydrogen production for use in a hydrogen fuel cell. Herein, we report on the efficacy of a laboratory-scale wastewater electrolysis cell (WEC) using real human waste for the first time with semiconductor electrode utilizing a mixed particle coating of bismuth oxide doped titanium dioxide $\left(\mathrm{BiO}_{x} / \mathrm{TiO}_{2}\right)$. A comprehensive environmental analysis has been coupled together with a robust kinetic model under the chemical reaction limited regime to investigate the role of various redox reactions mediated by chloride present in human waste. The oxidative elimination of the chemical oxygen demand (COD) and ammonium ion can be modelled using empirical, pseudo-first-order rate constants and current efficiencies (CE). In combination with an anaerobic pre-treatment step, human waste containing high-levels of COD, protein, and color are eliminated within 6 hours of batch treatment in the WEC. The reactor effluent has a residual inorganic total nitrogen (TN) concentration of $\sim 40 \mathrm{mM}$. The CE and specific energy consumption were $8.5 \%$ and $200 \mathrm{kWh}$ per kgCOD for the COD removal, $11 \%$ and 260 for $\mathrm{kWh}$ per $\mathrm{kgTN}$ for the TN conversion. The CE and energy efficiencies (EE) for hydrogen production were calculated to be $90 \%$ and $25 \%$, respectively.

Received 17th September 2013 Accepted 26th November 2013

DOI: $10.1039 / \mathrm{c3ra46699j}$

www.rsc.org/advances highly interrelated water-energy nexus ${ }^{3}$ require the water treatment and reuse practices to be on-site, energy sustainable, and economical with a minimal use of hydraulic retention time (HRT) and material costs.

In order to address some of these problems, we are exploring the use of electrochemical reactors or wastewater electrolysis cells (WEC) that have been designed to provide on-site wastewater treatment for water recycling and reuse coupled with energy storage. Electrochemical water oxidation to oxygen on metal oxides anodes is known to initiate by formation of surficial hydroxyl radicals and/or by direct electron transfer to surface-bound holes, ${ }^{\mathbf{4}-6}$ which can be used for the 'direct' oxidation of environmental contaminants. Wastewater with a sufficient level of electrical conductivity $(\sigma)$, such as dye wastewater and landfill leachate, has been investigated extensively for the electrochemical removal of pollutants. ${ }^{\mathbf{4}, 6}$ The near ubiquitous presence of chloride $\left(\mathrm{Cl}^{-}\right)$in the high-salinity wastewater often leads to the homogeneous 'indirect' oxidation via production of reactive chlorine species (RCS) including free chlorine $\left(\mathrm{Cl}_{2}, \mathrm{HOCl}, \mathrm{ClO}^{-}\right)^{\mathbf{4 , 6}}$ and chlorine radicals $\left(\mathrm{Cl}^{\circ}, \mathrm{Cl}_{2}^{-\cdot}\right) .^{7}$ The existence of chloride has been frequently reported to reduce specific energy consumption (SEC) for electrochemical oxidation of chemical pollutants by increasing $\sigma$ and substrate degradation rates at a given current (or potential). ${ }^{8-14}$

Energy conversion and storage are possible due to electron transfer to water or proton to produce hydrogen at the cathodes. This can lead to a much lower carbon footprint when compared 
to the steam reformation of methane to produce hydrogen. ${ }^{7,15,16}$ Under a sufficient solar irradiation, the WEC can be powered by an appropriate size of photovoltaic (PV) panels, ${ }^{7,15,17-19}$ to allow for a sustainable, and traditional-infrastructure-free approach to human waste treatment coupled with the generation of an energy-rich by-product (e.g., $\mathrm{H}_{2}$ ). Therefore, a PV-powered WEC (PWEC) has the potential to address the global needs for energy, water, and human health by using green chemistry without additional chemical reagents (e.g., $\mathrm{O}_{3}, \mathrm{H}_{2} \mathrm{O}_{2}, \mathrm{~S}_{2} \mathrm{O}_{8}{ }^{2-}$, etc.) to achieve a high-degree of BOD reduction.

It is possible to achieve energy efficient hydrogen production $^{20}$ coupled with chemical contaminant oxidation ${ }^{21,22}$ when utilizing electrochemically active anodes with high oxygen evolution reaction (OER) rates. Intrinsic cost-effectiveness and mechanical/chemical inertness are also important considerations for the proper design of electrodes., ${ }^{5,20}$ Electrodes with high OER overpotentials $(\eta)$, based on $\mathrm{SnO}_{2}, \mathrm{PbO}_{2}$ and $\mathrm{BDD}$ (Boron Doped Diamond), have been used exclusively for the direct electrochemical oxidation., ${ }^{\mathbf{4 , 6}, 23}$ In spite of superior current efficiencies for organic compound oxidation, these electrodes would not be suitable for energy conversion due to the lack of electrocatalytic activity and large energy losses. ${ }^{21,22}$ Facile $\mathrm{O}_{2} / \mathrm{Cl}_{2}$ evolution at active novel Pt group metal oxides $\left(\mathrm{RuO}_{2}\right.$ and $\left.\mathrm{IrO}_{2}\right)$ and combined usage with inert metal oxides $\left(\mathrm{TiO}_{2}, \mathrm{Ta}_{2} \mathrm{O}_{5}\right.$, and $\left.\mathrm{SnO}_{2}\right)$ to increase corrosion resistance allowed their applications for water splitting, chlor-alkali production, and wastewater electrooxidation. ${ }^{\mathbf{5 2 0 , 2 4 , 2 5}}$ However, the high material cost of low-abundance metals (i.e., $\mathrm{Ru}$ and Ir) is the major limitation for their commercial application. ${ }^{20}$ The electrocatalytic OER activity has long been ascribed to a reversible redox transition within the potential energy window of water splitting. ${ }^{5,20}$ In this regard, the pseudo-capacitance and dielectric permittivity of $\mathrm{Bi}_{2} \mathrm{O}_{3}$ provide a less costly approach for OER systems and for use in Faradaic supercapacitors. ${ }^{\mathbf{2 6}}$ Accelerated ion conductivity due to the intrinsic (disordered) oxygen vacancies and high polarizability due to the presence of $6 \mathrm{~s}^{2}$ lone pair in $\mathrm{Bi}$ enables $\mathrm{Bi}_{2} \mathrm{O}_{3}$ to be applied as a solid oxide fuel cell electrolyte. ${ }^{27}$ Based on the promising characteristics of this earth abundant metal oxide, our previous reports ${ }^{7,15,16,18,19}$ have demonstrated the feasibility of $\mathrm{Bi}$-doped $\mathrm{TiO}_{2}\left(\mathrm{BiO}_{x} / \mathrm{TiO}_{2}\right)$ electrodes for use in the WEC.

Herein, we report on the efficacy of the WEC equipped with the $\mathrm{BiO}_{x} / \mathrm{TiO}_{2}$ anode, as a novel dual-functioning approach for treatment and/or reuse of liquid human waste coupled with the simultaneous production of molecular hydrogen. Human urine is often a source of chloride present in domestic wastewater, which in turn can be oxidized to RCS resulting in the further organic compound oxidation and disinfection. The complex reaction network involved in chloride mediated indirect oxidation $^{\mathbf{4 , 6}}$ and the large number of operational variables that include current, applied cell voltage, pre-treatment, influent dilution, fluid-flow, and mixing ${ }^{28}$ require reliable kinetic models in order to explore of the role of each operational parameter. Consistent with the electrocatalytic behavior of our $\mathrm{BiO}_{x} / \mathrm{TiO}_{2}$ composite electrodes, a simple kinetic model is derived based on the measured rate constants for pollutant degradation, current efficiency, and specific energy consumption.

\section{Experimental}

\section{$2.1 \mathrm{BiO}_{x} / \mathrm{TiO}_{2}$ electrode preparation}

The multi-layered semiconductor electrodes were prepared by sequential deposition of mixed metal oxides ${ }^{29}$ as follows: (i) an anti-passivation layer of $\mathrm{IrO}_{2} / \mathrm{Ta}_{2} \mathrm{O}_{5}$ with a molar ratio of $73: 27$ (Ir : Ta), (ii) a sealing coat of $\mathrm{SnO}_{2} / \mathrm{Bi}_{2} \mathrm{O}_{3}$ at $\mathrm{Sn}: \mathrm{Bi}$ of $9: 1$, (iii) a slurry deposition of bismuth oxide doped $\mathrm{TiO}_{2}\left(\mathrm{BiO}_{x} / \mathrm{TiO}_{2}\right)$ nanoparticles with $\mathrm{Bi}$ : Ti of $1: 24$ and (iv) $\mathrm{BiO}_{x} / \mathrm{TiO}_{2}$ thin film (over-coat) deposition at a molar ratio of $1: 2$ (Bi : Ti). Each thermal decomposition procedure requires a specific precursor composition, heat treatment and repetition as described in the ESI. $\dagger$ In a recent report, we showed that the electrodes as prepared are dominated by the elemental composition of $\mathrm{Ti}, \mathrm{Bi}$, and $\mathrm{O}$ in electrochemically active outermost surface; ${ }^{18}$ thus we will refer to our composite anodes as $\mathrm{BiO}_{x} / \mathrm{TiO}_{2}$ electrode. The anti-passivation layer together with the sealing coat is known to enhance the robustness and electric conductivity. ${ }^{29}$

\subsection{Electrochemical setup}

The electrode modules used in this study consisted of a $\mathrm{BiO}_{x} /$ $\mathrm{TiO}_{2}$ anode, stainless steel (SS, Hastelloy C-22) cathode, and an $\mathrm{Ag} / \mathrm{AgCl} /$ saturated $\mathrm{KCl}$ reference electrode (BaSi Inc., USA). The effective area of the anode and cathode was $5.4 \mathrm{~cm}^{2}(2.7 \mathrm{~cm} \times$ $2 \mathrm{~cm}$ ). The distance between anode and cathode was $5 \mathrm{~mm}$, while the reference electrode was located as close as possible to the anode. Hereafter, the electrochemical potentials are always expressed in term of the normal hydrogen electrode (NHE). The electrochemical cells were powered by a potentiostat (SP-50, BioLogic, France) in which the applied anodic potential $\left(E_{\mathrm{a}}\right)$ was adjusted with continuous monitoring of the response current $(I)$ and cathodic potential $\left(E_{\mathrm{c}}\right)$.

\subsection{Electrode characterization}

The cyclic voltammetry (CV) data were collected using either a 50 $\mathrm{mM} \mathrm{NaCl}$ or a $50 \mathrm{mM} \mathrm{NaClO}_{4}$ electrolyte solution under quiescent conditions for three cycles consecutively without open-circuit resting. The scan rate and scan range were fixed at $5 \mathrm{mV} \mathrm{s}^{-1}$ and 0-3 V, respectively. The chrono-amperometric data were collected in stirred solutions with 10,30 and $50 \mathrm{mM} \mathrm{NaCl}$, where the $E_{\mathrm{a}}$ was varied from 1.5 to $3.5 \mathrm{~V}$ in $0.5 \mathrm{~V}$ increments. The resulting data were stored for $10 \mathrm{~min}$ at each $E_{\mathrm{a}}$ while resting the system in an open circuit for $5 \mathrm{~min}$ before adjustment of each potential increment. The CV and chrono-amperometric experiments were performed in single compartment cell with working volume of 275 $\mathrm{mL}$. In order to assess the direct oxidation efficacy of the $\mathrm{BiO}_{x} /$ $\mathrm{TiO}_{2}$ electrode, a bulk potentiostatic electrolysis $\left(E_{\mathrm{a}}: 3 \mathrm{~V}\right)$ was performed in $47.5 \mathrm{~mL} \mathrm{KH} \mathrm{PO}_{4}$ solution $(5.3 \mathrm{mM})$ whose small fraction $(2 \mathrm{~mL})$ was sequentially replaced with $10 \mathrm{mM} \mathrm{NaCOOH}$ solution in $10 \mathrm{~min}$ intervals without a change in $\sigma$. The variation in $I$ and $\left[\mathrm{HCO}_{2}{ }^{-}\right]$were monitored as functions of electrolysis time.

\subsection{Wastewater sample preparation}

Table 1 shows the average composition of urine collected from an Asian male (age: 30) and domestic wastewater (DWW). The 
Table 1 Composition of the as-received domestic wastewater (DWW), urine, and model septic tank effluent (STE1-4, see ESI $\dagger$ for the detailed preparation methods)

\begin{tabular}{|c|c|c|c|c|c|c|}
\hline $\mathrm{pH}$ & 7.1 & 6.6 & 8.9 & 9.0 & 9.1 & 9.0 \\
\hline Conductivity $\left(\mathrm{mS} \mathrm{cm}^{-1}\right)$ & 1.1 & 24 & 2.3 & 3.5 & 7.0 & 8.8 \\
\hline $\mathrm{TN}(\mathrm{mM} \mathrm{N})$ & 2.6 & 410 & 13 & 25 & 61 & 66 \\
\hline Urea $(\mathrm{mM})$ & $<0.01$ & 159 & 2.4 & 1.1 & 5.8 & 7.4 \\
\hline $\mathrm{NH}_{4}^{+}(\mathrm{mM})$ & 1.9 & 21 & 12 & 24 & 38 & 44 \\
\hline Protein $\left(\mathrm{mg} \mathrm{BSA} \mathrm{L}^{-1}\right)$ & 75 & 2300 & 160 & 250 & 520 & 280 \\
\hline Carbohydrate (mg glucose $\mathrm{L}^{-1}$ ) & 35 & 530 & 16 & 39 & 63 & 23 \\
\hline Organic acids (mM) & $<0.01$ & 6.9 & 0.02 & 1.6 & 3.1 & 0.09 \\
\hline
\end{tabular}

DWW was obtained at San Jose Creek Wastewater Treatment facility (tertiary treatment) operated by Sanitation Districts of Los Angeles County (USA). Samples were collected after a primary settling tank and stored in $4{ }^{\circ} \mathrm{C}$ before usage.

To simulate septic tank effluents (STEs), the urine was mixed with the DWW with volumetric ratio of $1: 3$ and anaerobically incubated at $35{ }^{\circ} \mathrm{C}$ for 2 days (conventional HRT in septic tanks ${ }^{30}$ ). Under these conditions, the high-molecular-weight organic compounds in urine can be biodegraded into lower molecular weight fragments by the microorganisms present in wastewater. Pre-treated urine was further diluted with the DWW with the mixing ratio of $1: 9$ (STE1), 1:4 (STE2) and 1:1 (STE3), which produced variable concentrations of mixed organic waste and chloride as shown in Table 1. Since the microbial concentration in DWW should be much smaller than in a septic tank, digested urine after 7 days of incubation was also tested without further dilution (STE4).

\subsection{WEC experiments}

The WEC setup consists of the electrode module in a single compartment electrolysis cell equipped with a side-branch sampling port and a gas outlet port on top. Initial working electrolyte and corresponding headspace volumes in the reactor were $55 \mathrm{~mL}$ and $20 \mathrm{~mL}$, respectively. Potentiostatic electrolyses $\left(E_{\mathrm{a}}: 3 \mathrm{~V}\right)$ were performed in 30 and $50 \mathrm{mM} \mathrm{NaCl}$ solutions for 3 hours to investigate the chloride oxidation kinetics in the absence of organic matter. The WEC experiments using urine (with and without dilution) and STEs proceeded for 6 hours, again with constant $E_{\mathrm{a}}(3 \mathrm{~V})$. Small aliquots of the electrolyte were collected for analyses without changing the working electrode surface area. During the middle (80-110 min) and the end phase (300-330 min) of the electrolyses, the sampling port was sealed with a rubber stopper for $30 \mathrm{~min}$ to introduce the headspace gas into a graded burette. The average total volumetric flow rate of gaseous products $(Q)$ was monitored and molar flow rate of hydrogen $\left(F_{\mathrm{H}_{2}}\right)$ was scaled based on the volumetric fraction of hydrogen $\left(X_{\mathrm{H}_{2}}\right)$ which was determined by a GC/TCD (Gas Chromatography with Thermal Conductivity Detector).

\subsection{Chemical analyses}

The $\mathrm{pH}$ and conductivity were monitored using a Mettler Toledo EL20 pH meter and VWR portable conductivity meter. In order to determine the chemical oxygen demand (COD), samples were digested in a low range dichromate digestion solution (3-150 mg $\mathrm{L}^{-1}$ ) in a COD reactor (DRB-200, Hach, USA) and quantified based on the absorbance at $420 \mathrm{~nm}$. The total nitrogen (TN) concentration was measured by the absorbance at $420 \mathrm{~nm}$ after treatment using a TN reagent set. Anions $\left(\mathrm{Cl}^{-}, \mathrm{ClO}_{3}{ }^{-}, \mathrm{NO}_{2}{ }^{-}, \mathrm{NO}_{3}{ }^{-}\right.$, $\left.\mathrm{HCO}_{2}{ }^{-}, \mathrm{C}_{2} \mathrm{O}_{4}{ }^{2-}, \mathrm{C}_{2} \mathrm{H}_{3} \mathrm{O}_{2}{ }^{-}\right)$and cations $\left(\mathrm{NH}_{4}{ }^{+}, \mathrm{Na}^{+}, \mathrm{Ca}^{2+}, \mathrm{Mg}^{2+}\right)$ were simultaneously determined by ion chromatography (DX-500, Dionex, USA) using an anion-exchange column Ionpac AS 19 and a cation-exchange column Ionpac CS 16. The protein and carbohydrate concentrations were measured using the Lowry method $^{31}$ and the phenol/sulfuric acid method. ${ }^{32}$ The total chlorine $\left(\mathrm{Cl}_{\mathrm{DPD}}\right)$ was measured using the DPD ( $N, N$-diethyl- $p$-phenylenediamine) method at a wavelength of $530 \mathrm{~nm}$. The concentration of urea was quantified based on the product ammonium concentration after hydrolysis with jack-bean urease. Absorbance measurements were made using an Agilent 8453 UV-VIS spectrophotometer. (Additional details are in the ESI $\dagger$ ).

\section{Results and discussion}

\subsection{Voltammetric characteristics of the WEC}

The space-time extent of pollutant oxidation is generally expected to increase with the applied potential (or current) when the effects of the current density $(J)$ on a desired current efficiency are not substantial. ${ }^{28,33}$ However, concomitant augmentation of the solution resistance $(I R)$ would be significant ${ }^{34}$ in the WEC since the $\sigma$ of electrolyte is much lower than in an industrial electrolyzer or chlor-alkali cell. Therefore, dealing with the WEC for energy conversion purposes, it is essential to investigate the variation of $I R$-compensated anodic potential $\left(E_{\mathrm{a}}-I R\right), J$, and cell voltage $\left(E_{\mathrm{a}}-E_{\mathrm{c}}\right)$ as a function of the $E_{\mathrm{a}}$. As shown in Fig. S1a of the ESI, $\dagger$ the $I R$ sharply increases as the $E_{\mathrm{a}}$ increases due to the exponential dependence of $I$ on the $E_{\mathrm{a}}-I R$. The increase of $E_{\mathrm{a}}-I R$ was marginal at an $E_{\mathrm{a}}$ above $3 \mathrm{~V}$ where additional power consumption should not contribute to the rate of electron transfer. Therefore, subsequent WEC 
experiments were carried out under potentiostatic conditions with the $E_{\mathrm{a}}$ of $3 \mathrm{~V}$. The energy loss at high applied potentials should be emphasized considering that the $E_{\mathrm{a}}-E_{\mathrm{c}}$ is the actual determinant of the energy consumption; in this study, an equivalent magnitude of $E_{\mathrm{c}}$ was required to manipulate the $E_{\mathrm{a}}$ (Fig. S1b in the ESI $\dagger$ ). ${ }^{33}$ This observation points out a potential problem, especially in dilute solution, with inferring that various reactive oxidants are present based on the cell voltage. For example, in $10 \mathrm{mM} \mathrm{NaCl}$ solution, the value of $E_{\mathrm{a}}-I R$ at an $E_{\mathrm{a}}-E_{\mathrm{c}}$ of $6.41 \mathrm{~V}$ was only $1.75 \mathrm{~V}(27 \%)$, smaller than the thermodynamic potential required to form $\mathrm{H}_{2} \mathrm{O}_{2}, \mathrm{O}_{3}$, as well as $\mathrm{OH}$, $\mathrm{Cl}$; and $\mathrm{Cl}_{2}{ }^{-}$. The reactive intermediates such as hydroxyl and chlorine radicals should be surface-bound to play a role without an $E_{\mathrm{a}}-I R$ exceeding their redox potentials $(E)$.

\subsection{Electrochemistry of the $\mathrm{BiO}_{x} / \mathrm{TiO}_{2}$ anode in dilute chloride solutions}

The $\mathrm{BiO}_{x} / \mathrm{TiO}_{2}$ has been used as a visible-light photocatalyst due to the characteristics of $\mathrm{Bi}_{2} \mathrm{O}_{3}$ including high refractive index and photoconductivity coupled with a relatively small band gap $(\sim 2.8 \mathrm{eV}) .{ }^{35}$ We also show that the $\mathrm{BiO}_{x} / \mathrm{TiO}_{2}$ anode is an excellent electrochemical catalyst for generation of oxygen and RCS. In Fig. 1, we illustrate the cyclic voltammetry of the $\mathrm{BiO}_{x} /$ $\mathrm{TiO}_{2}$ in $50 \mathrm{mM} \mathrm{NaCl}$ and $50 \mathrm{mM} \mathrm{NaClO}_{4}$ solutions. The onset potential of the anodic wave was observed near 1.16 V (NHE) in both electrolytes; this corresponds to an OER $\eta$ of $0.32 \mathrm{~V}$. The OER $\eta$ value of the $\mathrm{BiO}_{x} / \mathrm{TiO}_{2}$ is low comparably with those of $\mathrm{IrO}_{2}$ and $\mathrm{RuO}_{2}$ based electrodes. ${ }^{8,11,36}$ Since the OER $\eta$ value is closely related to the enthalpy of oxide transition, ${ }^{20}$ the facile OER activity of the $\mathrm{BiO}_{x} / \mathrm{TiO}_{2}$ anode can be attributed to the oxide ion conducting $\mathrm{BiO}_{x}$ rather than the electrochemically resistant $\mathrm{TiO}_{2}$. According to Comninellis, ${ }^{23}$ the OER on metal

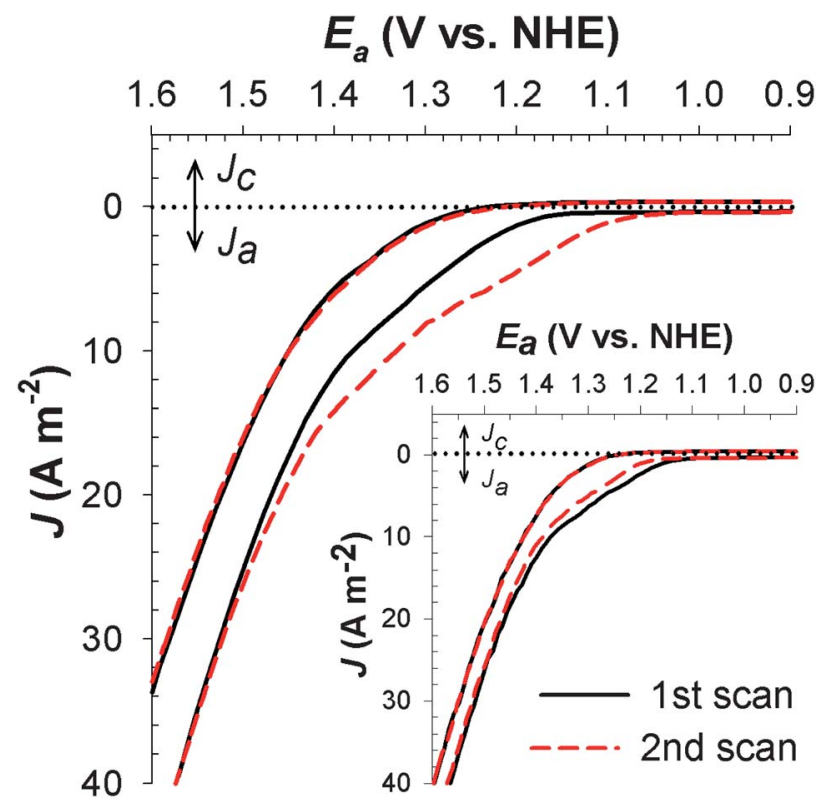

Fig. 1 Cyclic voltammetry (CV) of a single compartment electrolysis cell with $50 \mathrm{mM} \mathrm{NaCl}\left(\sigma: 5.5 \mathrm{mS} \mathrm{cm}^{-1}, R: 4.5 \Omega, \mathrm{pH}=6.6\right)$ or $50 \mathrm{mM}$ $\mathrm{NaClO}_{4}$ (inset, $\sigma: 5.1 \mathrm{mS} \mathrm{cm}{ }^{-1}, R: 4.6 \Omega, \mathrm{pH}=6.6$ ) solution $(275 \mathrm{~mL}$ ). oxides electrodes functions according to the following set of reactions:

$$
\begin{gathered}
\mathrm{MO}_{x}+\mathrm{H}_{2} \mathrm{O} \stackrel{k_{1}}{\longrightarrow} \mathrm{MO}_{x}(\cdot \mathrm{OH})+\mathrm{H}^{+}+\mathrm{e}^{-} \\
\mathrm{MO}_{x}(\mathrm{OH}) \stackrel{k_{2}}{\longrightarrow} \mathrm{MO}_{x+1}+\mathrm{H}^{+}+\mathrm{e}^{-} \\
\mathrm{MO}_{x}(\mathrm{OH}) \stackrel{k_{3 a}}{\longrightarrow} \mathrm{MO}_{x}+1 / 2 \mathrm{O}_{2}+\mathrm{H}^{+}+\mathrm{e}^{-} \\
\mathrm{MO}_{x+1} \stackrel{k_{3 b}}{\longrightarrow} \mathrm{MO}_{x}+1 / 2 \mathrm{O}_{2}
\end{gathered}
$$

The physi-sorbed $\left(\mathrm{MO}_{x}(\mathrm{OH})\right)$ and chemi-sorbed $\left(\mathrm{MO}_{x+1}\right)$ active oxygen would in turn react with $\mathrm{Cl}^{-}$to form the RCS, resulting in an indirect oxidation of environmental pollutants, while reactions of the $\mathrm{MO}_{x}(\mathrm{OH})$ or surface-trapped holes with electron donors is often classified as direct oxidation., ${ }^{\mathbf{4} 6}$ The contribution of the surface bound hydroxyl radicals can be estimated by monitoring the current variation at a fixed $E_{\text {a }}$ under a sequential addition of an organic electron donor (e.g., formate). ${ }^{37}$ As shown in Fig. S2 in the ESI, $\dagger$ the measured formate concentration did not deviate from the stepwise increasing time profile (without degradation), while the current variation was marginal as well. Therefore, the $\mathrm{MO}_{x}(\mathrm{OH})$ or the valence-band hole do not appear to be major contributors in oxidation pathways on the $\mathrm{BiO}_{x} / \mathrm{TiO}_{2}$ anode. The negligible heterogeneous surface degradation of formate might be partially attributed to a mass transport limitation to the anode surface. However, we propose that an internal oxidation of $\mathrm{Bi}$ (III) to the higher $\operatorname{Bi}(\mathrm{v})$ valence state would rapidly quench the $\mathrm{MO}_{x}(\mathrm{OH})$. Fig. S1c in the ESI $\dagger$ illustrates the chrono-amperometric current response in 10,30 , and $50 \mathrm{mM} \mathrm{NaCl}$ solutions. In a lower anodic potential region, the relationship between the $\log J$ and $E_{\mathrm{a}}-I R$ was governed by a linear Tafel equation, with a slope of $228 \mathrm{mV}$ per decade independent of the $\left[\mathrm{Cl}^{-}\right]$. The magnitude of the Tafel slope, which has been used to elucidate the rate determining step (RDS) in a multi-step reaction sequence, ${ }^{24,25,38}$ suggests that the formation of $\mathrm{MO}_{x}(\mathrm{OH})$ (eqn (1)) would be the RDS with a charge transfer coefficient around 0.25. The $\alpha$-phase $\mathrm{Bi}_{2} \mathrm{O}_{3}$ is known to have one quarter of an oxide vacancy per unit cell. ${ }^{27}$ In addition, partial substitutions of $\mathrm{Ti}^{4+}$ with the effective ionic radius $\left(r_{\text {ion }}\right)$ of $61 \mathrm{pm} \mathrm{by} \mathrm{Bi}^{3+}$ with $r_{\text {ion }}$ of $103 \mathrm{pm}$ provide for additional oxide vacancies that are favorable to the III/v valence state transition..$^{35}$ The minor direct oxidation efficacy which is related with oxygen deficiencies ${ }^{5}$ has been previously demonstrated for $\mathrm{RuO}_{x} / \mathrm{TiO}_{2}$ electrodes. ${ }^{\mathbf{8 , 1 2 , 2 1 , 3 9}}$

Several possible reaction mechanisms for the chlorine evolution reaction (CER) on the $\mathrm{RuO}_{2}$ or $\mathrm{RuO}_{2} / \mathrm{TiO}_{2}$ are consistent with the $\mathrm{MO}_{x+1}$ surface species as the dominant reactive site for chloride oxidation..$^{24,25,38}$ In a typical sequence, $\mathrm{Cl}^{-}$is initially oxidized to a surface bound $\mathrm{ClO}^{-}$(eqn (4a)), which in turn reacts with another chloride in bulk aqueous solution or on the electrode surface to produce $\mathrm{Cl}_{2}$ (eqn (4b)). In addition, an $E_{\mathrm{a}}-I R$ exceeding the $E$ of $\mathrm{Cl}_{2}{ }^{-} / \mathrm{Cl}^{-}$couple $(2.0 \mathrm{~V})$ should allow for the generation of chlorine radicals (eqn (4c) and (5c)), whose decay rate constants to $\mathrm{Cl}_{2}$ are in the order of $10^{9} \mathrm{M}^{-1} \mathrm{~s}^{-1}$. Regardless of the terminal step in the mechanism, 
the RCS generation is characterized as first order in $\left[\mathrm{Cl}^{-}\right]$with a pseudo-steady-state approximation on $\mathrm{MO}_{x}\left(\mathrm{ClO}^{-}\right) .{ }^{25}$ At circumneutral $\mathrm{pH}$, the $\mathrm{Cl}_{2}$ reacts with water to form hypochlorous acid, hypochlorite, $\mathrm{H}^{+}$, and $\mathrm{Cl}^{-}$(eqn (5a) and (5b)).

$$
\begin{gathered}
\mathrm{MO}_{x+1}+\mathrm{Cl}^{-} \stackrel{k_{4 a}}{\longrightarrow} \mathrm{MO}_{x}\left(\mathrm{ClO}^{-}\right) \\
\mathrm{MO}_{x}\left(\mathrm{ClO}^{-}\right)+\mathrm{Cl}^{-}+2 \mathrm{H}^{+} \stackrel{k_{4 b}}{\longrightarrow} \mathrm{MO}_{x}+\mathrm{Cl}_{2}+\mathrm{H}_{2} \mathrm{O} \\
\mathrm{MO}_{x}\left(\mathrm{ClO}^{-}\right)+\mathrm{Cl}^{-}+\mathrm{H}^{+} \rightarrow \mathrm{MO}_{x}(\mathrm{OH})+\mathrm{Cl}_{2}^{-\cdot} \\
\mathrm{Cl}_{2}+\mathrm{H}_{2} \mathrm{O} \stackrel{k_{5 a}, k_{-5 a}}{\longrightarrow} \mathrm{HOCl}+\mathrm{Cl}^{-}+\mathrm{H}^{+} \\
\mathrm{HOCl}^{\stackrel{k_{5 b}, k_{-5 b}}{\longrightarrow} \mathrm{ClO}^{-}+\mathrm{H}^{+}} \\
\mathrm{Cl}_{2}{ }^{-\cdot} \leftrightarrow \mathrm{Cl}^{\cdot}+\mathrm{Cl}^{-}
\end{gathered}
$$

In the subsequent scan in $\mathrm{NaCl}$ solution (dashed line in Fig. 1), there was a significant decrease in the current onset potential to $1.06 \mathrm{~V}$. The earlier onset of the anodic current observed in the chloride solution could be ascribed to the formation of chlorate, which is a major by-product detected in the wastewater electrolysis (vide infra), along with the build-up of the RCS during the initial scan. The second onset potential did not explicitly coincide with the $E$ values of $\mathrm{ClO}_{3}{ }^{-} / \mathrm{Cl}_{2}(1.47 \mathrm{~V}$ at $\mathrm{pH} 0,0.97 \mathrm{~V}$ at $\mathrm{pH} 7), \mathrm{ClO}_{3}{ }^{-} / \mathrm{HOCl}(1.44 \mathrm{~V}$ at $\mathrm{pH} 0,0.92 \mathrm{~V}$ at $\mathrm{pH} 7)$, and $\mathrm{ClO}_{3}{ }^{-} / \mathrm{ClO}^{-}(1.36 \mathrm{~V}$ at $\mathrm{pH} 0,0.94 \mathrm{~V}$ at $\mathrm{pH} 7)$ couple. However, given the bulk solution near neutral $\mathrm{pH}$, it is conceivable to assume that $\mathrm{HOCl}$ or $\mathrm{ClO}^{-}$should be the primary reductants leading to chlorate production (eqn (6)). ${ }^{\mathbf{4 0 , 4 1}}$ The reaction scheme described herein neglects perchlorate formation and direct oxidation of chloride to chlorate, ${ }^{42}$ which are reported to occur in a very high anodic bias (in the order of $10^{3} \mathrm{~A}$ $\mathrm{m}^{-2}$ in terms of $\left.J\right) .^{\mathbf{4 0 , 4 3}}$

$$
\begin{gathered}
2 \mathrm{MO}_{x+1}+\mathrm{ClO}^{-} \stackrel{k_{6 a}}{\longrightarrow} 2 \mathrm{MO}_{x}+\mathrm{ClO}_{3}{ }^{-} \\
2 \mathrm{MO}_{x+1}+\mathrm{HOCl} \stackrel{k_{6 b}}{\longrightarrow} 2 \mathrm{MO}_{x}+\mathrm{ClO}_{3}{ }^{-}+\mathrm{H}^{+}
\end{gathered}
$$

\subsection{Electrochemical kinetics in dilute chloride solutions}

The polarization curve of Fig. S1c in the ESI $\dagger$ shows an inflection in the current response with an augmentation of $J$ in 30 and $50 \mathrm{mM} \mathrm{NaCl}$ solutions. An incremental transition of the Tafel slope is generally interpreted as an artifact of a mass transport limitation or a shift in the RDS. ${ }^{24}$ If we consider that the RDS at a low $E_{\mathrm{a}}$ is due to the electron transfer reaction of eqn (1), then the reactions involving the $\mathrm{MO}_{x+1}$ (eqn (3b), (4a), and (6)) become important as the $E_{\mathrm{a}}$ increases. In the chemical reaction limited regime, heterogeneous reactions including OER, CER and chlorate evolution reactions should not significantly depend on the $E_{\mathrm{a}}-I R .^{23}$ At a relatively large value of $\eta$, the active sites would be virtually saturated with the higher oxide valence states; i.e., quasi constant $\left[\mathrm{MO}_{x+1}\right]$ in the Nernstian equilibrium between $\mathrm{MO}_{x}$ and $\mathrm{MO}_{x+1}$. If we define free chlorine (FC) as the sum of $\mathrm{Cl}_{2}, \mathrm{HOCl}$, and $\mathrm{ClO}^{-},{ }^{\mathbf{1 4 , 2 8 , 4 0}}$ then the electrochemical conversion of the chloride can be treated as a simple first-order reaction in series, where the overall kinetics is governed by eqn (7)-(9) (the complete derivation in the ESI $\dagger$ ). Even in the presence of chlorine radicals, their short lifetimes should allow the [RCS] to be comparable with [FC], which was quantified as $\mathrm{Cl}_{\mathrm{DPD}}$ in this study. The utilization of the FC as a single component can be rationalized by an existence of the most abundant reaction intermediate, whose speciation would be dependent on the wastewater composition and the operating conditions.

$$
\begin{gathered}
\frac{\mathrm{d}\left[\mathrm{Cl}^{-}\right]}{\mathrm{d} t}=-k_{4 a}\left[\mathrm{MO}_{x+1}\right]\left[\mathrm{Cl}^{-}\right]=-k_{4}^{\text {eff }}\left[\mathrm{Cl}^{-}\right] \\
\frac{\mathrm{d}[\mathrm{FC}]}{\mathrm{d} t}=k_{4 a}\left[\mathrm{MO}_{x+1}\right]\left[\mathrm{Cl}^{-}\right]-k_{6 a}\left[\mathrm{MO}_{x+1}\right]^{2}[\mathrm{FC}] \\
=k_{4}^{\text {eff }}\left[\mathrm{Cl}^{-}\right]-k_{6}^{\text {eff }}[\mathrm{FC}] \\
\frac{\mathrm{d}\left[\mathrm{ClO}_{3}^{-}\right]}{\mathrm{d} t}=k_{6 a}\left[\mathrm{MO}_{x+1}\right]^{2}[\mathrm{FC}]=k_{6}^{\text {eff }}[\mathrm{FC}]
\end{gathered}
$$

Fig. 2 shows the evolution of the $\mathrm{Cl}^{-}, \mathrm{FC}$, and $\mathrm{ClO}_{3}{ }^{-}$ concentrations during a potentiostatic electrolysis in chloride solutions with initial chloride concentrations $\left(\left[\mathrm{Cl}^{-}\right]_{0}\right)$ of 30 and $50 \mathrm{mM}$. Anionic chlorine species with other oxidation states $\left(\mathrm{ClO}_{2}{ }^{-}, \mathrm{ClO}_{4}{ }^{-}\right)$were not detected. Despite the different current response $\left(J=232 \pm 20 \mathrm{~A} \mathrm{~m}^{-2}\right.$ in $\left[\mathrm{Cl}^{-}\right]_{0}$ of $30 \mathrm{mM}, 364 \pm 23 \mathrm{~A}$ $\mathrm{m}^{-2}$ in $50 \mathrm{mM}$ ), the concentration of each chlorine species when normalized by $\left[\mathrm{Cl}^{-}\right]_{0}$ is governed by identical kinetic parameters. This observation demonstrates that the CER and chlorate evolution reactions are in chemical reaction limited regime. The chlorate evolution rate was found to increase with time; this provides further corroboration that the oxidation of FC is responsible for the chlorate formation. ${ }^{\mathbf{4 0 , 4 1}}$ The apparent first-order behavior for the reactions taking place on the $\mathrm{BiO}_{x} /$ $\mathrm{TiO}_{2}$ anode suggests that a plug-flow or sequential-batch reactor would be preferred to a continuous stirred-tank reactor in terms of the yield and selectivity for the FC. The least-squares estimates for the rate coefficients are $0.17 \mathrm{~h}^{-1}$ for $k_{4}^{\text {eff }}$ and $0.37 \mathrm{~h}^{-1}$ for $k_{6}^{\text {eff }}$ using all data sets. However, there are some deviations from the regression lines that are most likely due to potential interference of cathodic reactions, which reduce the RCS to chloride. $^{7,15}$ As shown in Fig. 2a (inset), the $k_{4}^{\text {eff }}$ slightly decreased with the augmentation of the FC concentration. The cathodic FC reduction constitutes a null electrochemical cycle with the $\mathrm{Cl}$ species as an electron relay, ${ }^{7}$ reducing the apparent rate and current efficiency of the desired reactions (pollutants removal and hydrogen generation). With another least-squares estimation using the initial data points, we obtained $0.24 \mathrm{~h}^{-1}$ for $k_{4}^{\text {eff }}$ and $0.36 \mathrm{~h}^{-1}$ for $k_{6}^{\text {eff }}$, which can be used to estimate the rate constants for the homogeneous reactions between the RCS and electron donors (vide infra).

The instantaneous current efficiency (ICE) and general current efficiency (GCE) are figures of merit, which have been frequently used to evaluate the selectivity of the passed charge towards the chemical contaminants oxidation or RCS generation., ${ }^{\mathbf{4} 6}$ For an electrolysis cell with chloride and water as electron donors, the ICE for FC and chlorate can be expressed as follows (from eqn (3b), (8) and (9)): 

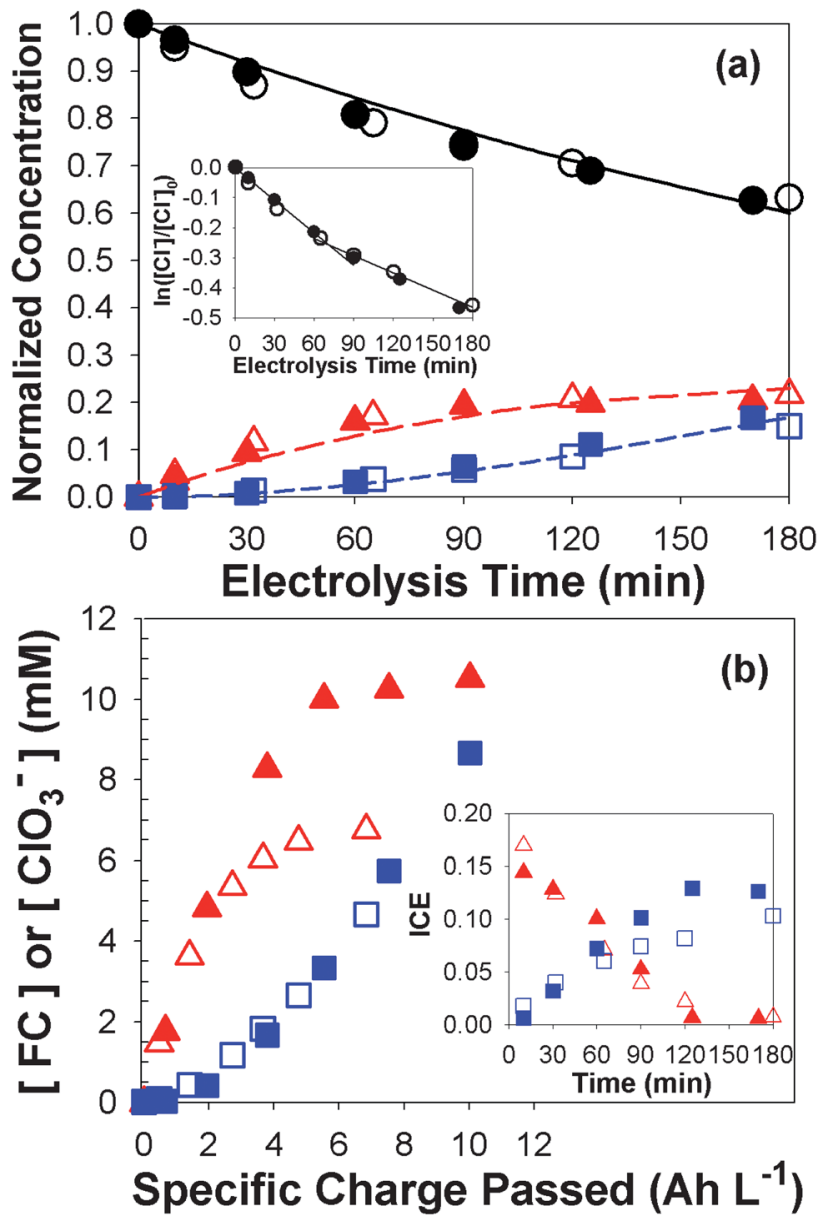

Fig. 2 The variation of chloride (circle), free chlorine (triangle), and chlorate (square) concentration as a function of (a) electrolysis time and (b) specific charge passed during potentiostatic $\left(E_{\mathrm{a}}=3 \mathrm{~V}\right)$ electrolysis in $30 \mathrm{mM}$ (filled, $R=7.0 \Omega$ ) and $50 \mathrm{mM}$ (empty, $R=5.0 \Omega$ ) $\mathrm{NaCl}$ solution $(55 \mathrm{~mL})$. The inset figures in (a) and (b) show the logarithmic normalized chloride concentration and the instantaneous current efficiency versus the electrolysis time.

$$
\begin{aligned}
\mathrm{ICE}_{\mathrm{FC}} & =\frac{I_{\mathrm{FC}}}{I_{\mathrm{O}_{2}}+I_{\mathrm{FC}}+I_{\mathrm{ClO}_{3}-}}=\frac{2\left(k_{4}^{\text {eff }}\left[\mathrm{Cl}^{-}\right]-k_{6}^{\text {eff }}[\mathrm{FC}]\right)}{2 k_{3}^{\text {eff }}+2 k_{4}^{\text {eff }}\left[\mathrm{Cl}^{-}\right]+4 k_{6}^{\text {eff }}[\mathrm{FC}]} \\
& =\frac{2 V F \mathrm{~d}[\mathrm{FC}]}{I \mathrm{~d} t} \\
\mathrm{ICE}_{\mathrm{ClO}_{3}{ }^{-}} & =\frac{I_{\mathrm{ClO}_{3}{ }^{-}}}{I_{\mathrm{O}_{2}}+I_{\mathrm{FC}}+I_{\mathrm{ClO}_{3}}}=\frac{4 k_{6}^{\text {eff }}[\mathrm{FC}]}{2 k_{3}^{\text {eff }}+2 k_{4}^{\text {eff }}\left[\mathrm{Cl}{ }^{-}\right]+4 k_{6}^{\text {eff }}[\mathrm{FC}]} \\
& =\frac{4 V F \mathrm{~d}\left[\mathrm{ClO}_{3}{ }^{-}\right]}{I \mathrm{~d} t}
\end{aligned}
$$

where, $I_{\mathrm{O}_{2}}, I_{\mathrm{FC}}$, and $I_{\mathrm{ClO}_{3}}$ - refer to the current used for generation of oxygen, $\mathrm{FC}$, and chlorate, $k_{3}^{\text {eff }}$ represents $k_{3 b}\left[\mathrm{MO}_{x+1}\right]$, while $V$ is electrolyte volume and $F$ is Faraday's constant. Fig. 2b depicts $[\mathrm{FC}]$ and $\left[\mathrm{ClO}_{3}{ }^{-}\right]$as a function of the specific charge passed for which the tangential slope is proportional to the ICE. The GCE at a specific time, defined as the charge required for an observed product divided by the total passed charge, is visualized by the slope of a secant line toward the initial point. As readily expected from eqn (10) and (11) and the analytical solutions of eqn (7)-(9) (eqn (S8) and (S10) in the ESI $\dagger$ ), the ICE $_{\mathrm{FC}}$ monotonically decreases along with the electrolysis time or passed charge, while the $\mathrm{GCE}_{\mathrm{FC}}$ is always higher than the $\mathrm{ICE}_{\mathrm{FC}}$ (vice versa for the chlorate). The initial $\mathrm{ICE}_{\mathrm{FC}}$ should be a strong function of $\left[\mathrm{Cl}^{-}\right]_{0}$ (eqn (S9) in the ESI $\dagger$ ), consistent with the literature on chlorine evolution with metal oxide electrodes. ${ }^{9,44}$ However, the initial $\mathrm{ICE}_{\mathrm{FC}}$ was near 0.15 irrespective of the difference in $\left[\mathrm{Cl}^{-}\right]_{0}$, while the effects of $\left[\mathrm{Cl}^{-}\right]_{0}$ were more discernible for the initial ICE for chlorate formation. This observation indicates that the OER is not completely determined by the $\mathrm{MO}_{x+1}$ dismutation (eqn (3b)), but is also influenced by the electron transfer reactions (eqn (1) and (2)), where $k_{3}^{\text {eff }}$ could increase in part with the $\sigma$ or $\left[\mathrm{Cl}^{-}\right]_{0}$.

The observed first-order decrease of $\left[\mathrm{Cl}^{-}\right]$can also be a consequence of a mass transport limitation, whose impact can be roughly assessed by the limiting current density $\left(J_{\mathrm{L}}\right)$ as shown in eqn (12). ${ }^{34,45}$

$$
J_{\mathrm{L}}=n F k_{\mathrm{m}}^{\mathrm{Cl}}\left[\mathrm{Cl}^{-}\right] \text {, }
$$

where, $n$ is the number of electron for $\mathrm{Cl}^{-}$oxidation (2) and $k_{\mathrm{m}}^{\mathrm{Cl}}$ is the mass transfer coefficient for $\mathrm{Cl}^{-}$. If $k_{\mathrm{m}}^{\mathrm{Cl}}$ is assumed to be on the order of $10^{-5} \mathrm{~m} \mathrm{~s}^{-1},{ }^{46,47}$ then the $J_{\mathrm{L}}$ can be estimated to be $96 \mathrm{~A}$ $\mathrm{m}^{-2}$ for $50 \mathrm{mM} \mathrm{NaCl}$ solutions and $58 \mathrm{~A} \mathrm{~m}^{-2}$ for $30 \mathrm{mM}$ solutions. These values are approximately $70 \%$ higher than the current density used for the FC formation ( $J$ multiplied by ICE $_{\mathrm{FC}}$ ). This implies that chloride oxidation would not be in the transport-controlled regime. Even if a mass transport limitation is operative, the forms of kinetic equations are essentially the same.

\subsection{Electrochemical treatment of fresh urine}

Preliminary experiments were performed to assess the performance of the WEC when fresh human urine is oxidized under potentiostatic condition $\left(E_{\mathrm{a}}: 3 \mathrm{~V}\right)$. During the electrochemical oxidation, intense foaming was observed, most likely due to an interaction of the electrolytically produced bubbles (i.e., $\mathrm{O}_{2}$ and $\mathrm{H}_{2}$ ) with proteins. In addition, precipitation of $\mathrm{CaCO}_{3}$ and $\mathrm{Mg}(\mathrm{OH})_{2}$ occurred on the cathode. The scale deposition is facilitated by high $\mathrm{pH}$ in the vicinity of the cathodes, presumably due to the consumption of protons during the hydrogen production. In this situation, subsequent electrolyses were carried using fresh urine that was diluted with Milli-Q water by a volume ratio of $1: 3$. The cathodic deposit in calcareous form was corroborated by monotonic decreases of $\left[\mathrm{Ca}^{2+}\right]$ and $\left[\mathrm{Mg}^{2+}\right]$ as shown in Fig. S3b (inset) in the ESI. $\dagger$

In spite of the $\left[\mathrm{Cl}^{-}\right]_{0}$ in diluted urine of $45 \mathrm{mM}$, the observed rate of $\mathrm{Cl}^{-}$decay as well as the production rates of $\mathrm{FC}$ and $\mathrm{ClO}_{3}{ }^{-}$ (as shown in Fig. S3a in the ESI $\dagger$ ) were much smaller than those measured in $\mathrm{NaCl}$ solution. In this experiment, the $\mathrm{Cl}_{\mathrm{DPD}}$ can be composed of either FC or combined chlorine, although each contribution cannot be estimated precisely by the chlorine mass balance analysis (see analytical details in the ESI $\dagger$ ) due to the bulk $\mathrm{pH}$ (6.6) smaller than the $\mathrm{p} K_{\mathrm{a}}$ of $\mathrm{HOCl}$ (7.5). The slower kinetics that were observed during the chlorine redox cycle can be attributed to facile homogeneous reactions of FC, with the various electron donors present in urine, being reduced back to chloride 
rather than further oxidized to chlorate. However, there was little net elimination of COD after 6 hours (Fig. S3b in the ESI $\dagger$ ), which is most likely due to presence of macro-molecular organic compounds. The proteins concentration in the diluted urine was 8 times higher than in the DWW (Table 1). The decomposition of high-molecular-weight organic compounds, which may be refractory to dichromate digestion in COD analysis, may have caused partial increase of the detectable COD. Since $E$ of $\mathrm{Cr}_{2} \mathrm{O}_{7}{ }^{2-}$ / $\mathrm{Cr}^{3+}$ (1.36 $\mathrm{V}$ at $\mathrm{pH}$ 0) exceeds the corresponding potentials of $\mathrm{ClO}^{-} / \mathrm{Cl}^{-}$or $\mathrm{HOCl} / \mathrm{Cl}^{-}$at circum-neutral $\mathrm{pH}$, the $\mathrm{FC}$ would transform the recalcitrant organics to be kinetically amenable to the dichromate. The concentration profile of protein (Fig. S3b in the ESI $\dagger$ ), in terms of the abundance of peptide bonds determined via the Lowry method, ${ }^{31}$ gave a pseudo first-order rate coefficient of $0.23 \mathrm{~h}^{-1}$; this indicates that the organic transformation by the FC involves cleavages of the peptide bonds.

About $80 \%$ of the initial TN in diluted urine was contributed by urea (Table 1 ) with additional contributions from creatinine, uric acid, amino acids, and protein. Fig. S3c in the ESI $\dagger$ shows that the degradation of the nitrogen containing organics resulted in the production of ammonium ion, nitrate, and gaseous nitrogen expressed by the decrease in the TN concentration. The urea degradation by the FC is known to initiate by sequential chlorination of the urea to tetrachlorourea which is further oxidized to the chloramine species. ${ }^{48}$ The inorganic combined chlorine eventually yields ammonium ion, nitrogen gas (by dismutation of chloramines in so-called breakpoint chlorination mechanism), and nitrate via further oxidation by FC. ${ }^{\text {9,49,50 }}$ The high concentration of refractory organics in the fresh urine required an extended electrolysis time for apparent COD conversion. In light of this observation, a combination with biological pre-treatment including anaerobic digestion is used to enhance pollutants conversion and to increase the energy efficiency of the electrochemical treatment, ${ }^{34,36,47}$ as demonstrated in this study (vide infra).

\subsection{Chlorine transformation in the WEC with model septic tank effluents}

During the potentiostatic ( $\left.E_{\mathrm{a}}: 3 \mathrm{~V}\right)$ WEC experiments with STEs, $J$ was observed to be comparable to those in sodium chloride solution (Fig. S4a in the ESI†). Therefore, we assume that the redox kinetics for the various chlorine species are in chemical reaction limited regime. The main oxidizable components in the STEs were ammonium ion and organic compounds in terms of COD (Table 1). Their homogeneous reactions with the FC can be expressed by the following non-stoichiometric reactions:

$$
\begin{aligned}
& \mathrm{COD}+\mathrm{FC} \stackrel{k_{13}}{\longrightarrow} \text { Product }+\mathrm{Cl}^{-} \\
& 2 \mathrm{NH}_{4}^{+}+3 \mathrm{FC} \stackrel{k_{14}}{\longrightarrow} \mathrm{N}_{2}+3 \mathrm{Cl}^{-} \\
& \mathrm{NH}_{4}^{+}+4 \mathrm{FC} \stackrel{k_{15}}{\longrightarrow} \mathrm{NO}_{3}^{-}+4 \mathrm{Cl}^{-}
\end{aligned}
$$

Assuming that bimolecular reactions occur between the ammonium ion and FC with overall second order kinetics would be ideal, since reactions (14) and (15) are most likely to proceed via sequential chlorination, producing chloramines as reaction intermediates. ${ }^{9}$ In this context, the governing equations for FC in the presence of oxidizable chemical species can be modified as:

$$
\begin{aligned}
\frac{\mathrm{d}[\mathrm{FC}]}{\mathrm{d} t}= & k_{4}^{\mathrm{eff}}\left[\mathrm{Cl}^{-}\right]-k_{6}^{\mathrm{eff}}[\mathrm{FC}]-k_{13}[\mathrm{FC}][\mathrm{COD}] \\
& -\left(3 k_{14}+4 k_{15}\right)[\mathrm{FC}]\left[\mathrm{NH}_{4}^{+}\right]
\end{aligned}
$$

Fig. 3c illustrates the evolution of $\mathrm{Cl}_{\mathrm{DPD}}$, following a typical break-point chlorination curve, ${ }^{49}$ whose concentration was much smaller than $\left[\mathrm{Cl}^{-}\right]_{0}$. In addition, the sum of apparent $\left[\mathrm{Cl}^{-}\right]$including $\left[\mathrm{ClO}^{-}\right],\left[\mathrm{ClO}_{3}^{-}\right]$and $\left[\mathrm{Cl}_{\mathrm{DPD}}\right]$ was always conserved with standard deviations less than $0.1 \mathrm{mM}$. The initial pH of the STEs was near 9 (Table 1), due to urea hydrolysis during anaerobic pre-treatment. The bulk $\mathrm{pH}$ did not change significantly during electrolysis because of the inherent buffering capacity of STEs and bicarbonate generation from COD oxidation. Therefore, $\mathrm{Cl}_{\mathrm{DPD}}$ should be dominated by the sum of the combined chlorines, which followed a typical time profile for intermediates of reactions in series. The insignificant concentrations of FC again imply facile homogeneous reactions between FC and the constituent pollutants, which allows for a pseudo-steady-state approximation for the FC concentration $\left([\mathrm{FC}]_{\mathrm{SS}}\right)$. With a quasi-constant FC concentration, eqn (16) indicates a linear correlation of $\left[\mathrm{Cl}^{-}\right]$with $[\mathrm{COD}]$ and $\left[\mathrm{NH}_{4}^{+}\right]$for each experimental condition as demonstrated in Fig. $3 \mathrm{~d}$ and e. At given values of $k_{4}^{\text {eff }}$ and $k_{6}^{\text {eff }}$ under quasi-saturated active sites, the $[\mathrm{FC}]_{\mathrm{Ss}}$ will be a function of the initial chloride concentration $\left(\left[\mathrm{Cl}^{-}\right]_{0}\right)$, the initial ratio of pollutants to chloride concentration $\left([\mathrm{COD}]_{0} /\left[\mathrm{Cl}^{-}\right]_{0},\left[\mathrm{NH}_{4}{ }^{+}\right]_{0} /\left[\mathrm{Cl}^{-}\right]_{0}\right)$, and the rate coefficients for specific pollutant degradation $\left(k_{13}, k_{14}, k_{15}\right)$.

In the STEs electrolysis, a major by-product was again found to be chlorate ion whose production rate appeared to be nearly unchanged with time (zero-order kinetics), as shown in Fig. 3b and expressed by eqn (9) at a constant $[\mathrm{FC}]_{\text {Ss. }}$. Using the value of $k_{6}^{\text {eff }}$, the $[\mathrm{FC}]_{\mathrm{Ss}}$ recorded in the slopes of the chlorate concentration profiles were estimated to be $0.34,1.4,2.8$ and $6.3 \mathrm{mM}$ (higher than the bulk $\left[\mathrm{Cl}_{\mathrm{DPD}}\right]$ ). As noted in the literature, ${ }^{34}$ there should be concentration gradients for the heterogeneous reactants and products in electrode vicinity, often referred to boundary layer or reaction cage. Owing to higher reactivity and molecular weight, the FC gradient would be more pronounced than the chloride gradient so that the $[\mathrm{FC}]_{\mathrm{Ss}}$ in the boundary layer can exceed the bulk $[\mathrm{FC}]_{\mathrm{Ss}}$. Given our previous arguments, the characteristic mass balance equations can be written for the near-surface of the anode and bulk solution separately as:

$$
\frac{\mathrm{d}[\mathrm{FC}]_{\mathrm{SS}}^{\mathrm{A}}}{\mathrm{d} t}=k_{4}^{\mathrm{eff}}\left[\mathrm{Cl}^{-}\right]-k_{6}^{\mathrm{eff}}[\mathrm{FC}]_{\mathrm{SS}}^{\mathrm{A}}-\frac{k_{\mathrm{m}}^{\mathrm{FC}}}{\delta}\left([\mathrm{FC}]_{\mathrm{SS}}^{\mathrm{A}}-[\mathrm{FC}]_{\mathrm{SS}}^{\mathrm{B}}\right)=0
$$

$$
\begin{aligned}
\frac{\mathrm{d}[\mathrm{FC}]_{\mathrm{SS}}^{\mathrm{B}}}{\mathrm{d} t}= & \frac{k_{\mathrm{m}}^{\mathrm{FC}}}{\delta}\left([\mathrm{FC}]_{\mathrm{SS}}^{\mathrm{A}}-[\mathrm{FC}]_{\mathrm{SS}}^{\mathrm{B}}\right)-[\mathrm{FC}]_{\mathrm{SS}}^{\mathrm{B}}\left\{k_{13}[\mathrm{COD}]\right. \\
& \left.+\left(3 k_{14}+4 k_{15}\right)\left[\mathrm{NH}_{4}^{+}\right]\right\}=0
\end{aligned}
$$

In this case, $[\mathrm{FC}]_{\mathrm{SS}}^{\mathrm{A}}$ and $[\mathrm{FC}]_{\mathrm{SS}}^{\mathrm{B}}$ are the quasi-steady-state $\mathrm{FC}$ concentrations in the boundary layer and in bulk, $k_{\mathrm{m}}^{\mathrm{FC}}$ is the mass transfer coefficient for the FC, and $\delta$ is the depth of 

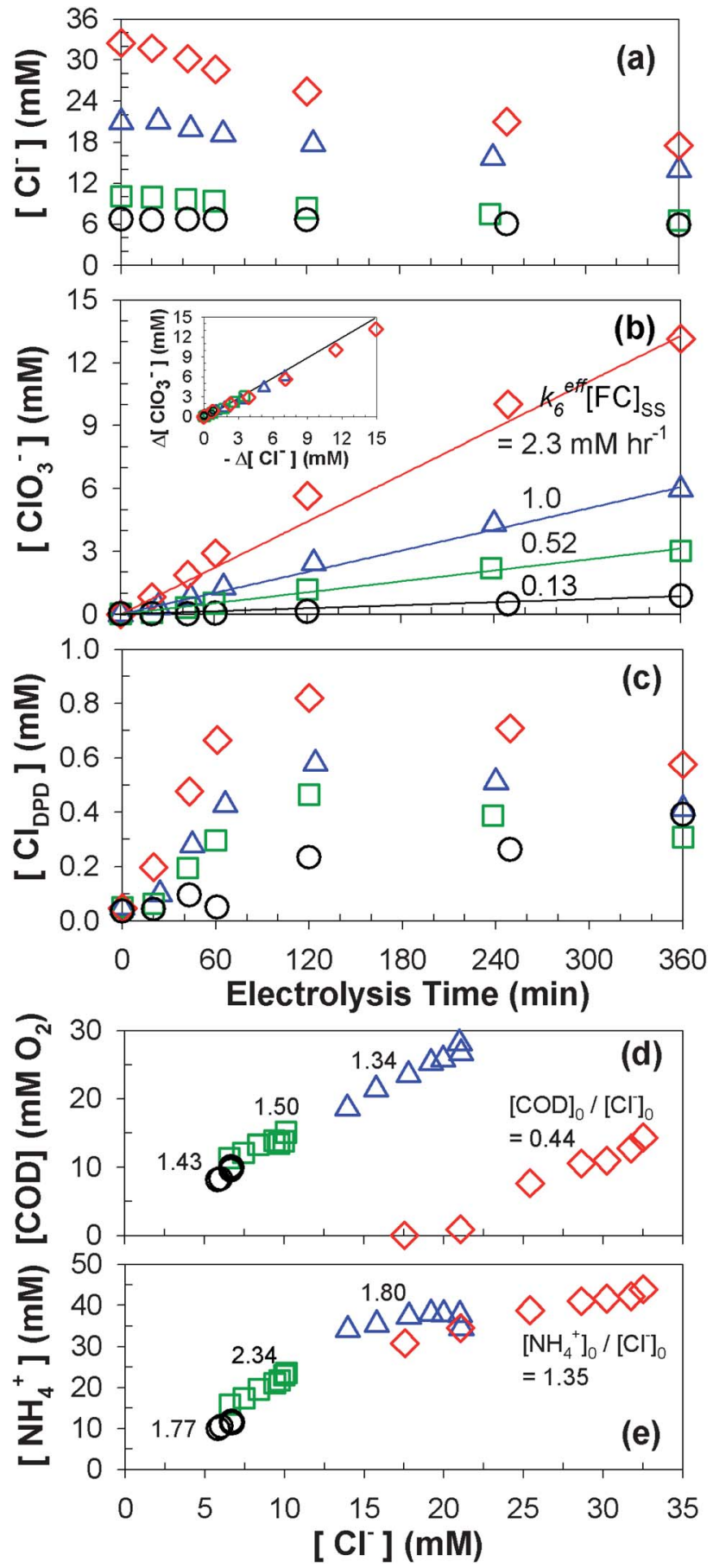

Fig. 3 Time profiles of (a) chloride, (b) chlorate, and (c) $\mathrm{Cl}_{D P D}$ concentration together with ((b), inset) scatter plots of increase of chlorate versus decrease of chloride concentration, (d) COD versus chloride concentration, and (e) ammonium ion versus chloride concentration in potentiostatic ( $\left.E_{\mathrm{a}}: 3 \mathrm{~V}\right) \mathrm{WEC}$ experiments with model septic tank effluents; STE1 (circle), STE2 (square), STE3 (triangle), STE4 (diamond).

boundary layer. When $[\mathrm{FC}]_{\mathrm{SS}}^{\mathrm{B}}$ is much lower than $[\mathrm{FC}]_{\mathrm{SS}}^{\mathrm{A}}$ and the $k_{\mathrm{m}}^{\mathrm{FC}} / \delta$ is constant, eqn (17) and $\mathrm{S} 14$ in the $\mathrm{ESI} \dagger$ indicate that $[\mathrm{FC}]_{\mathrm{SS}}^{\mathrm{A}}$ and the corresponding chlorate production rate are strongly dependent on the initial chloride concentration, ${ }^{40}$ as shown in Fig. 3b. On the other hand, as can be inferred from eqn (18), [FC $]_{\mathrm{SS}}^{\mathrm{B}}$ should be affected by the initial concentration of pollutants $\left([\mathrm{COD}]_{0},\left[\mathrm{NH}_{4}{ }^{+}\right]_{0}\right)$ as well.

\subsection{COD Removal characteristics in WECs with model septic tank effluents}

Fig. 4 illustrates the evolution of the COD concentration during the WEC experiments using STEs. The COD conversion after 6 hours electrolysis was $15 \%, 25 \%$ and $34 \%$ for STE1-3, respectively, whereas almost complete mineralization (i.e., conversion to $\mathrm{CO}_{2}$ ) of COD was observed for STE4. The pseudo-steady-state assumption for FC allows us to characterize the COD degradation kinetics by a pseudo-first-order rate constant, $k_{\mathrm{COD}}^{\mathrm{eff}}$.

$$
\frac{\mathrm{d}[\mathrm{COD}]}{\mathrm{d} t}=-k_{13}[\mathrm{FC}]_{\mathrm{SS}}^{\mathrm{B}}[\mathrm{COD}]=-k_{\mathrm{COD}}^{\mathrm{eff}}[\mathrm{COD}]
$$

From a series of nonlinear regressions of eqn (19), we can estimate $k_{\mathrm{COD}}^{\text {eff }}$ which is an order of magnitude higher for STE4 $\left(0.43 \mathrm{~h}^{-1}\right)$ than for the others $\left(0.041-0.066 \mathrm{~h}^{-1}\right)$. The rate constants depend on $[\mathrm{COD}]_{0} /\left[\mathrm{Cl}^{-}\right]_{0}$ rather than $\left[\mathrm{Cl}^{-}\right]_{0}$, in agreement with previous reports ${ }^{14,33,51}$ in which the observed rate constants increased with the relative COD concentration but were not altered by influent dilution. The initial ratio of pollutants-to-chloride concentration would be an important determinant of $[\mathrm{FC}]_{\mathrm{SS}}^{\mathrm{B}}$, as inferred from eqn (18) with $[\mathrm{FC}]_{\mathrm{SS}}^{\mathrm{A}}$ as a strong function of $\left[\mathrm{Cl}^{-}\right]_{0}$. Therefore, an extended anaerobic treatment resulted in STE4 having a lower pollutants-to-chloride ratio than the other STEs (Fig. 3d and e) and superior COD conversion. In addition, a lower fraction of recalcitrant organics in STE4 (Table 1) also contributed to the higher $k_{\mathrm{COD}}^{\text {eff }}$ by an augmented $k_{13}$. Assuming the DWW is analogous to the flushing water for excreta, the recipe of STE4 is rationalized by a low usage of flushing water, threefold volume of urine, as would be the scenario in communities with water shortages. The HRT required for STE with a higher flushing would be comparable since the dilution does not affect the ratio of pollutants to chloride concentration, or even smaller when sticking to an effluent water quality criteria.

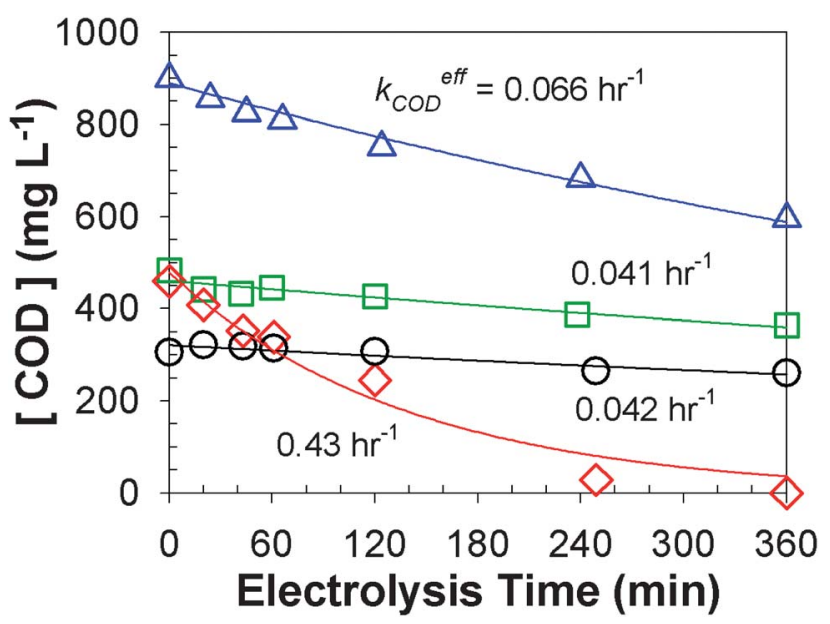

Fig. 4 Time profiles of COD concentration in potentiostatic $\left(E_{\mathrm{a}}: 3 \mathrm{~V}\right)$ WEC experiments with model septic tank effluents; STE1 (circle), STE2 (square), STE3 (triangle), STE4 (diamond). 
Consequently, the results for STE4 strongly demonstrate that our WEC is suitable for efficient toilet wastewater treatment system in a relatively short HRT without external chemical dosages, if combined with proper anaerobic pre-treatment unit. It should be noted that the pre-treatment would require much shorter times than 7 days, since the biological concentration in septic tanks would be much greater than in DWW.

Fig. S5 in the ESI $\uparrow$ details the transformation characteristics for the organic compounds in terms of scatter plots for protein, carbohydrates, and carboxylic acids versus the COD concentration. As in the case of COD, the pseudo first-order rate constant for protein degradation ( $\left.k_{\text {protein }}^{\text {eff }}\right)$ was also much higher for STE4 $\left(2.5 \mathrm{~h}^{-1}\right)$ than for STE1-3 (1.2-1.5 $\left.\mathrm{h}^{-1}\right)$. In addition, the observed $k_{\text {protein }}^{\text {eff }}$ exceeds $k_{\mathrm{COD}}^{\text {eff }}$ by more than an order of magnitude for STE1-3, which suggests that the FC would preferentially attack the nucleophilic sites of organic macromolecules by electrophilic substitution reactions. ${ }^{7,52}$ The reaction between FC and the peptides, which have second-order rate constant on the order of $10^{6}-10^{7} \mathrm{M}^{-1} \mathrm{~s}^{-1}$, is known to initiate by chloramination of terminal amine group. ${ }^{52}$ The cleavage of peptides bonds should produce measurable COD (carbonyl compounds and amines with shorter chain lengths), because initial protein degradation was not accompanied by a noticeable decrease of COD (Fig. S5a in the ESI $\dagger$ ). On the contrary, the COD degradation caused increases in carbohydrate and carboxylate concentration (Fig. S5b and S5c in the ESI $\dagger$ ), as is reported in a previous work using municipal wastewater. ${ }^{19}$ While carboxylate ions (e.g., formate, oxalate, and acetate) are often the observed products of organic compound oxidation, ${ }^{39,53}$ the increase in apparent carbohydrate may be due to the release of mono- or oligo-saccharide from decomposition of glycoproteins. The reaction of FC with electron-rich glycosidic bonds in poly-saccharides should also yield simple sugars, which can form hydroxymethylfurfural in the phenol/sulphuric acid analytical method. ${ }^{32}$ The reactivity of the FC with oxygenated moieties (alcohol and carboxyl functional groups) in carbohydrates and carboxylic acids are known to be relatively slow. ${ }^{\mathbf{5 2 , 5 4}}$ Nevertheless, the accumulation of these organic compounds did not significantly contribute to the residual COD of STE4.

\subsection{Nitrogen removal characteristics in the WEC with model septic tank effluents}

The evolution of nitrogen containing compounds, another major constituent of STEs, is illustrated in Fig. 5. The conversions of $\mathrm{TN}$ and $\mathrm{NH}_{4}{ }^{+}$after the 6 hours electrolysis were observed to be less than that of COD, and the TN conversion had a relative order of STE4 $(39 \%)>$ STE2 $(25 \%)>$ STE3 $(18 \%)>$ STE1 (13\%). The kinetics of the ammonium ion oxidation can be described in terms of the pseudo-first-order rate constants, $k_{\mathrm{am}}^{\mathrm{eff}}$, as follows:

$$
\frac{\mathrm{d}\left[\mathrm{NH}_{4}^{+}\right]}{\mathrm{d} t}=-\left(3 k_{14}+4 k_{15}\right)[\mathrm{FC}]_{\mathrm{SS}}^{\mathrm{B}}\left[\mathrm{NH}_{4}^{+}\right]=-k_{\mathrm{am}}^{\mathrm{eff}}\left[\mathrm{NH}_{4}^{+}\right]
$$

As shown in Fig. 5b, the magnitude of $k_{\mathrm{am}}^{\mathrm{eff}}$ was not simply correlated with $[\mathrm{FC}]_{\mathrm{SS}}^{\mathrm{B}}$ as in the case of COD and the highest rate constant was observed for STE2. Table 1 and Fig. 5a (inset) show

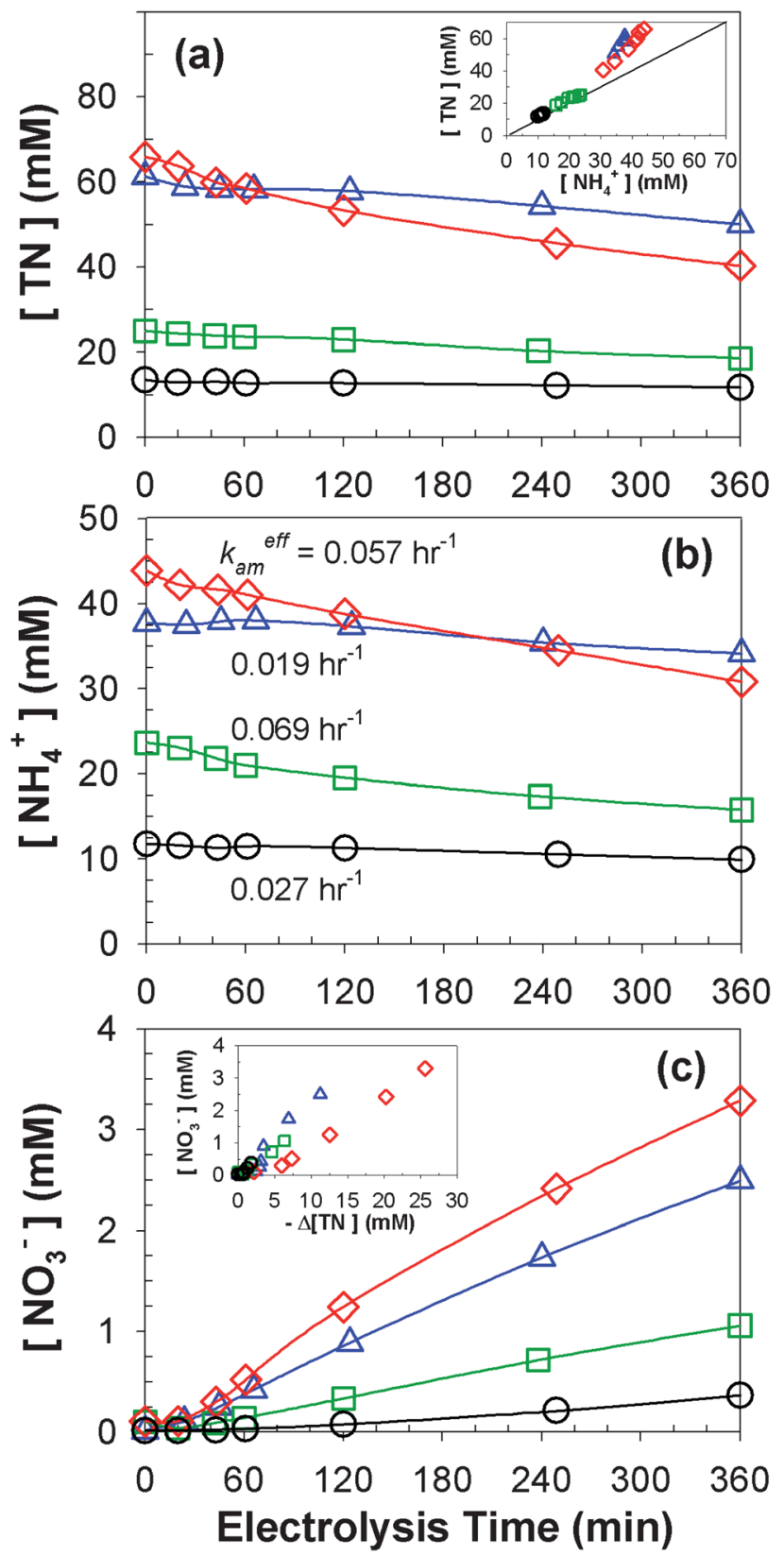

Fig. 5 Time profiles of (a) TN, (b) $\mathrm{NH}_{4}{ }^{+}$, and (c) $\mathrm{NO}_{3}{ }^{-}$concentration together with scatter plots for ((a), inlet) $\mathrm{TN}$ versus $\mathrm{NH}_{4}{ }^{+}$concentration and ((c), inlet) $\mathrm{NO}_{3}{ }^{-}$versus removed $\mathrm{NH}_{4}{ }^{+}$concentration in potentiostatic $\left(E_{\mathrm{a}}: 3 \mathrm{~V}\right)$ WEC experiments with model septic tank effluents; STE1 (circle), STE2 (square), STE3 (triangle), STE4 (diamond).

that ammonium ion constituted $60-70 \%$ of TN in STE3-4 and even larger fractions for STE1-2 (higher dilution with DWW). The initial organic nitrogen, in terms of $[\mathrm{TN}]_{0}-\left[\mathrm{NH}_{4}{ }^{+}\right]_{0}-$ $\left[\mathrm{NO}_{3}{ }^{-}\right]_{0}$, was attributed to urea by more than $50 \%$. As discussed above, the degradation of urea and other nitrogen containing moieties (amines, amides, amino acids, and peptides) will produce ammonium ion via organic chloramine formation and consecutive oxidation. ${ }^{\mathbf{4 8 , 5 2}}$ As a result, apparent $k_{\mathrm{am}}^{\text {eff }}$ values were lower for STE3-4 despite the higher levels of [FC $]_{\text {SS }}^{\mathrm{B}}$. Fig. 5a (inset) further visualizes that the ostensible decay rates of TN 
exceeds those of ammonium for STE3-4. This observation together with low values of $\left[\mathrm{Cl}_{\mathrm{DPD}}\right]$ (Fig. 3c) suggests that gaseous nitrogen generation may not be limited by the dismutation reactions of the chloramine species. The relative reactivity of FC towards amides (including urea) is not as high as the second-order rate constants of FC with ammonium ion, primary/secondary amines, amino acids, and peptides. ${ }^{52}$ On the other hand, the observed rates of the TN decay were also greater than nitrate generation rate, as shown in Fig. 5c (inset), which is more obvious for STE4. Although the mechanism and kinetics for the breakpoint chlorination are not fully known, the dominance of combined chlorine in the $\mathrm{Cl}_{\mathrm{DPD}}$ allows us to conclude that the disproportionation of chloramines is favored relative to their further oxidation to nitrate, as the chloramine concentration increases. Previous studies on ammonium ion removal from landfill leachates ${ }^{50}$ and anaerobic digestion effluents ${ }^{55}$ reported similar results in that $\mathrm{N}_{2}$ formation is favored over nitrate formation as $J$ or $\left[\mathrm{Cl}^{-}\right]_{0}$ increase.

In the case of the STE4 effluent which had the highest TN conversion, the WEC effluents still had significant nitrogen concentrations ( $40 \mathrm{mM} \mathrm{TN})$, which were primarily in the form of ammonium ion (76\%) and nitrate $(8.2 \%)$. If we imagine the bioavailability of residual nitrogen, the treated water can then be regarded as a liquid fertilizer if used for irrigation water.

\subsection{Current efficiency and energy consumption of the WEC with model septic tank effluents}

Based on the kinetic model in this study, the instantaneous current efficiencies for COD degradation and for production of $\mathrm{N}_{2}, \mathrm{NO}_{3}{ }^{-}$, and $\mathrm{ClO}_{3}{ }^{-}$can be expressed as follows:

$$
\begin{aligned}
\mathrm{ICE}_{\mathrm{COD}} & =\frac{4 k_{14}[\mathrm{FC}]_{\mathrm{SS}}^{\mathrm{B}}[\mathrm{COD}]}{2 k_{3}^{\text {eff }}+2 k_{4}^{\text {eff }}\left[\mathrm{Cl}^{-}\right]+4 k_{6}^{\text {eff }}[\mathrm{FC}]_{\mathrm{SS}}^{\mathrm{A}}}=-\frac{4 V F \mathrm{~d}[\mathrm{COD}]}{I \mathrm{~d} t} \\
\mathrm{ICE}_{\mathrm{N}_{2}} & =\frac{3 k_{14}[\mathrm{FC}]_{\mathrm{SS}}^{\mathrm{B}}\left[\mathrm{NH}_{4}^{+}\right]}{2 k_{3}^{\text {eff }}+2 k_{4}^{\text {eff }}\left[\mathrm{Cl}{ }^{-}\right]+4 k_{6}^{\text {eff }}[\mathrm{FC}]_{\mathrm{SS}}^{\mathrm{A}}}=-\frac{3 V F \mathrm{~d}[\mathrm{TN}]}{I \mathrm{~d} t} \\
\mathrm{ICE}_{\mathrm{NO}_{3^{-}}} & =\frac{8 k_{15}[\mathrm{FC}]_{\mathrm{SS}}^{\mathrm{B}}\left[\mathrm{NH}_{4}^{+}\right]}{2 k_{3}^{\text {eff }}+2 k_{4}^{\text {eff }}\left[\mathrm{Cl}^{-}\right]+4 k_{6}^{\text {eff }}[\mathrm{FC}]_{\mathrm{SS}}^{\mathrm{A}}}=\frac{8 V F \mathrm{~d}\left[\mathrm{NO}_{3}{ }^{-}\right]}{I \mathrm{~d} t} \\
\mathrm{ICE}_{\mathrm{ClO}_{3^{-}}} & =\frac{6 k_{6}^{\text {eff }}[\mathrm{FC}]_{\mathrm{SS}}^{\mathrm{A}}}{2 k_{3}^{\text {eff }}+2 k_{4}^{\text {eff }}\left[\mathrm{Cl}{ }^{-}\right]+4 k_{6}^{\text {eff }}[\mathrm{FC}]_{\mathrm{SS}}^{\mathrm{A}}}=\frac{6 V F \mathrm{~d}\left[\mathrm{ClO}_{3}{ }^{-}\right]}{I \mathrm{~d} t}
\end{aligned}
$$

In these equations, the [COD] should be expressed in molar concentration units $\left(\mathrm{mM} \mathrm{O}_{2}\right)$, while $\mathrm{N}_{2}$ is assumed to totally account for the gaseous nitrogen production. The ICE for chlorate production is expressed based on 6-electron transferred from chloride. Compared to the ICE for chloride oxidation in the absence of pollutants (eqn (10)-(11), Fig. 2b) with significant time variations, the differential concentrations of COD, TN, nitrate, and chlorate appeared to be almost linearly correlated with the specific charge passed (Fig. S6 in the ESI $\dagger$ ). Accordingly, the ICE did not deviate much from the GCE. These findings can be explained in terms of the pseudo first-order rate constants for pollutant degradation $\left(k_{\mathrm{COD}}^{\mathrm{eff}}, k_{\mathrm{am}}^{\mathrm{eff}}\right)$ that are much lower than $k_{4}^{\text {eff }}$ and $k_{6}^{\text {eff }}$. The ICE for organic compound degradation on non-active electrodes such as BDD has sometimes been reported to approach unity initially but decrease with time, as limited by the mass transport of substrate to the anode surface. ${ }^{54}$

A series of linear regressions of the differential concentrations on the specific charge passed can be used to estimate the mean current efficiencies, as illustrated by Fig. 6a. The results as well as eqn (S18)-(S21) in the ESI $\dagger$ indicate that the current efficiencies of the FC mediated oxidation are influenced substantially by $\left[\mathrm{Cl}^{-}\right]_{0}$ itself, ${ }^{\mathbf{1 0 , 1 3 , 2 8 , 5 6}}$ rather than by the pollutants-to-chloride ratio. The rate of pollutant removal should be a function of $\left[\mathrm{Cl}^{-}\right]_{0}$ only, since it is proportional to the $[\mathrm{FC}]_{\mathrm{SS}}^{\mathrm{B}}$ multiplied by the pollutant concentrations. At a given $\left[\mathrm{Cl}^{-}\right]_{0}$, eqn (S18)-(S21) in the ESI $\dagger$ further indicate that the relative concentration and reactivity towards the FC govern the charge consumption for each substrate. For example, in STE4, $k_{\mathrm{COD}}^{\text {eff }}$ exceeds $k_{\mathrm{am}}^{\text {eff }}$ by greater extent than in the other STEs, which was balanced by the lowest value of $[\mathrm{COD}] /\left[\mathrm{NH}_{4}{ }^{+}\right]$ratio. Independent of the specific STE composition, the charge required for COD reduction was comparable with that for $\mathrm{N}_{2}$ production, about
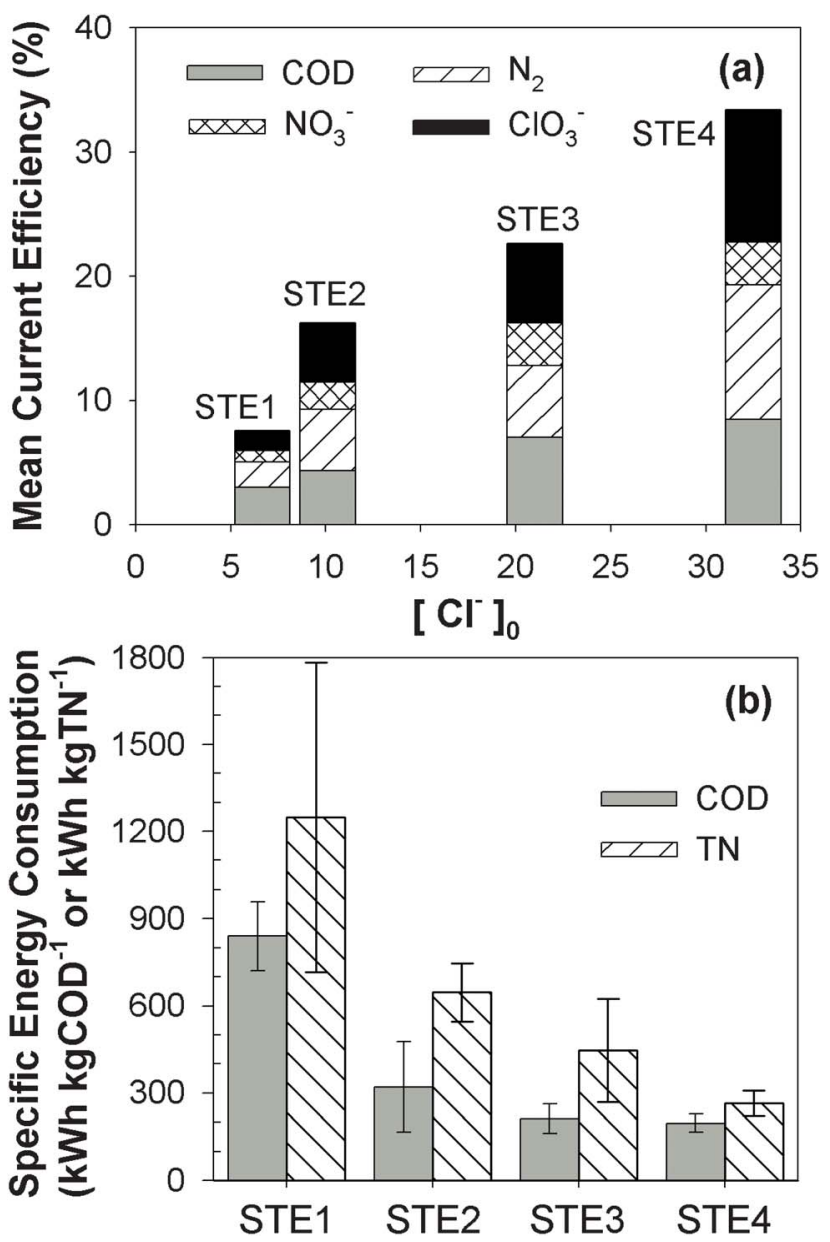

Fig. 6 (a) Average current efficiency for COD, nitrogen, and chlorine conversion, and (b) specific energy consumption for COD and total nitrogen on average in potentiostatic $\left(E_{\mathrm{a}}: 3 \mathrm{~V}\right) \mathrm{WEC}$ experiments with model septic tank effluents. Error bars represent the standard deviation. 
half of which was consumed for nitrate production. Even though the 'regression toward the mean' analysis would underestimate the individual ICE, the sum of eqn (21)-(24) as the total current used other than OER was less than $50 \%$. In a previous direct measurement of oxygen evolution from an electrolysis of a chloride solution, we estimated the current efficiency of the OER to be less than $25 \% .^{15}$

As can be seen in Fig. 6b, the energy consumption for unit removal of pollutants also monotonically decreased with the increase in $\left[\mathrm{Cl}^{-}\right]_{0}$. However, the influence of $\left[\mathrm{Cl}^{-}\right]_{0}$ on the SEC is not as significant as on the ICE due to the large increment of $J$ with $\left[\mathrm{Cl}^{-}\right]_{0}$ (Fig. S4a in the ESI $\uparrow$ ). These observations suggest that an influent dilution (increase in flushing volume) might reduce the HRT to achieve an effluent quality criteria (vide supra), but an increase of energy consumption is inevitable. ${ }^{14,51}$ The kinetic model presented herein predicts minor effects of $J$ on the observed rate constants in the chemical reaction limited regime. This model is in general agreement with previous reports on $\mathrm{RuO}_{2}$ which experimentally showed a saturation dependence of the observed rate constants on $J .^{12,33,34,57}$ It is clear that current density plays a crucial role in the direct oxidation rate but not in the indirect oxidation rate. ${ }^{33,57}$ Under these conditions, further increases in $J$ should favor OER rather than CER, which in turn decreases the current efficiency of pollutant oxidation but significantly increases the solution resistance, energy loss and SEC. ${ }^{14}$ Therefore, a reduction in SEC is expected with an effort to adjust the $E_{\mathrm{a}}$ to maximize the desired current efficiency.

\subsection{Hydrogen production in WEC with model septic tank effluents}

Fig. 7 depicts the quantitative estimates for hydrogen generation as a function of the average $J$ value. The rate of total gas production $(Q)$ almost linearly increased with the average $J$. The volumetric fraction of hydrogen $\left(X_{\mathrm{H}_{2}}\right)$ was about $40 \%$ under current densities less than $150 \mathrm{~A} \mathrm{~m}^{-2}$ (STE1), while increased to near $60 \%$ at higher current densities. However, the dependency of $X_{\mathrm{H}_{2}}$ on $J$ was not obvious when taking into account the measurement error (coefficient of variation: $11 \%$ in maximum) in the GC/TCD analysis. The adverse contribution of gases initially present in the connection tube may explain the lower $X_{\mathrm{H}_{2}}$ for STE1. The remaining fractions of the gaseous products would include oxygen, water vapor, nitrogen, carbon dioxide, chlorine, ammonia, and hydrogen sulphide (with minor contribution). The molar flow rate of hydrogen $\left(F_{\mathrm{H}_{2}}\right)$ is used to estimate the current efficiency for hydrogen generation $\left(\mathrm{CE}_{\mathrm{H}_{2}}\right)$ to be $50 \%$ for STE1, increasing to $90 \%$ for STE2-4. The hydrogen evolution reaction (HER) has a well-known reaction sequence ${ }^{20}$ that proceeds by combination of eqn (25) with either eqn (26) or eqn (27):

$$
\begin{gathered}
\mathrm{HA}+\mathrm{C}+\mathrm{e}^{-} \rightarrow \mathrm{C}\left(\mathrm{H}^{-}\right)+\mathrm{A}^{-} \\
\mathrm{C}\left(\mathrm{H}^{\cdot}\right)+\mathrm{HA}+\mathrm{e}^{-} \rightarrow \mathrm{H}_{2}+\mathrm{C}+\mathrm{A}^{-} \\
2 \mathrm{C}\left(\mathrm{H}^{\cdot}\right) \rightarrow \mathrm{H}_{2}+2 \mathrm{C}
\end{gathered}
$$

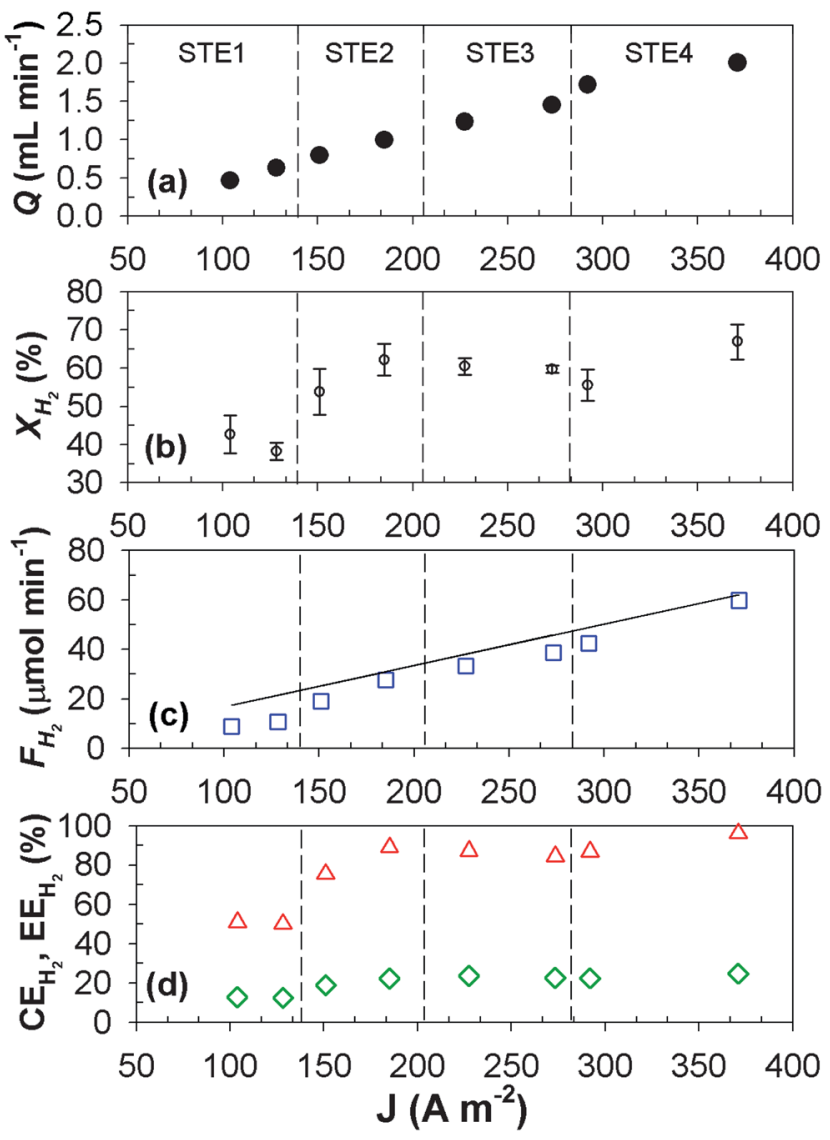

Fig.7 Dependency of (a) generation rate of total gaseous products $(Q$, solid circle), (b) volumetric fraction of hydrogen $\left(X_{\mathrm{H}_{2}}\right.$, void circle), (c) molar generation rate of hydrogen ( $F_{\mathrm{H}_{2}}$ square), (d) current and energy efficiency ( $C E$ in triangle and $E E$ in diamond) for hydrogen generation on average current density (J) during gas collection (80-110 min and $300-330 \mathrm{~min}$ ) in potentiostatic ( $\left.E_{\mathrm{a}}: 3 \mathrm{~V}\right)$ WEC experiments with model septic tank effluents. Error bars in (b) represent the standard deviations of repetitive GC/TCD measurement and the reference line in (c) shows theoretical $F_{\mathrm{H}_{2}}$ with CE of $100 \%$.

where $\mathrm{C}$ stands for a cathodically active site for the HER and A is the conjugate base of the proton $\left(\mathrm{OH}^{-}\right.$or null term in circumneutral $\mathrm{pH}$ ). The main constituent acting as the active sites is presumed to be $\mathrm{Ni}$, in the case of Hastelloy $\mathrm{C}-22$ that was used in this study. Ni belongs to a near-summit group of the volcano plots under basic conditions..$^{20} \mathrm{Ni}$-based binary or ternary metal composites (with $\mathrm{Mo}, \mathrm{Co}, \mathrm{Cd}$, and $\mathrm{Fe}$ ) have been thoroughly investigated for their catalytic HER activity that is dependent on the bond strength between the metal surface and adsorbed hydrogen.

Competitive electron acceptors including oxygen, nitrate, chlorate, and FC can interfere with the HER. The cathodic potential $\left(E_{\mathrm{c}}\right)$, which ranged from -2.4 to $-2.8 \mathrm{~V}$, is sufficiently below the $E$ of $\mathrm{O}_{2} / \mathrm{HO}_{2}{ }^{-}(-0.54 \mathrm{~V}$ at pH 7$)$ as well as positive $E$ (spontaneous reduction) of $\mathrm{NO}_{3}{ }^{-} / \mathrm{NO}_{2}{ }^{-}(0.42 \mathrm{~V}$ at $\mathrm{pH} 7), \mathrm{ClO}_{3}{ }^{-} /$ $\mathrm{ClO}^{-}$and $\mathrm{ClO}^{-} / \mathrm{Cl}^{-}$. The RCS species are clearly the major scavengers of HER and their effects on the $\mathrm{CE}_{\mathrm{H}_{2}}$ have been documented in our previous reports. For example, Park et al. ${ }^{7}$ reported that an injection of organic electron donors during electrolysis in $\mathrm{NaCl}$ solution results in a sharp increase of $\mathrm{CE}_{\mathrm{H}_{2}}$ 
by quenching the RCS. In the present report, anodically generated FC species should engage in facile reactions with pollutants in the bulk phase before being transported to the cathode surface, ${ }^{34}$ as demonstrated by the quasi-steady-state FC with a very small bulk-phase concentration $\left([\mathrm{FC}]_{\mathrm{SS}}^{\mathrm{B}}\right)$. The reduction of oxygen to superoxide radical and resulting reactive oxygen species (ROS) were thought to influence the oxidation of pollutants. However, the roles of ROS appear to be marginal in this study because the conversion of COD was insignificant when the chloride concentration was low (STE1).

In spite of the relatively high current efficiency, the energy efficiency for hydrogen generation $\left(\mathrm{EE}_{\mathrm{H}_{2}}\right)$ was observed near $25 \%$ for STE2-4, which is much lower than an idealized electrolysis unit. The $\mathrm{EE}_{\mathrm{H}_{2}}$ has been reported to increase with lowering cell voltage $\mathrm{e}^{\mathbf{1 9}}$ and in synergy with photocatalytic hydrogen evolution on the $\mathrm{BiO}_{x} / \mathrm{TiO}_{2}$ electrode under direct solar radiation. ${ }^{18}$ The energy losses due to the intrinsic overpotential, the ohmic drop, along with the various side reactions in the complex electrolyte system within the WEC may be compensated by a net saving of energy for water treatment and the added costs of electrolyte addition. The US DOE (ref. 58) estimated that the wastewater collection and treatment consumes about $60 \%$ of the energy requirements for water supply. The impurities in the gaseous product narrow the usage of the hydrogen to an internal combustion (IC) engine without an added purification procedure. Based on the energy efficiency of the current hydrogen IC engines of $35 \%$, a $10 \%$ reduction of the SEC is expected with using the hydrogen as a secondary energy source for the WEC.

\section{Outlook for the future}

Conventional water reuse criteria for non-restricted urban reuse applications are generally based on a BOD of $30 \mathrm{mg} \mathrm{L}^{-1} \cdot{ }^{3}$ The electrochemically treated water for the STE4 showed negligible COD, suggesting that the treated water is suitable for reuse as toilet flushing water and for irrigation. The relatively facile removal of protein further implies an efficient disinfection of coliforms through complete breakage of bacterial cells and inactivation owing to the reduced carbon source. Since color is also an important consideration for reuse of treated wastewater, we note that the yellowish color was nearly eliminated during WEC treatment as shown in Fig. S7 in the ESI. $\dagger$ However, chlorate production poses a potential health risk, since several drinking water guidelines recommend chlorate concentrations lower than $10 \mu \mathrm{M}^{40}$ The high level of chlorate most likely will not be a significant problem when using the treated water only for toilet flushing. The chlorate formation can be reduced with an increase in hydraulic mixing in the WEC resulting in an increase of $k_{\mathrm{m}}^{\mathrm{FC}}$, as inferred from eqn (S14) and (S17) in the ESI. $\dagger$ A proper selection of cathode materials, known to have a high activity for nitrate reduction (such as bimetallic $\mathrm{Cu} / \mathrm{Zn}$ (ref. 59)), can be another potential solution to facilitate chlorate reduction to chloride under actual operating conditions. These enhancements would be beneficial with respect to increase the efficiency of pollutant oxidation even though chlorate reduction could compete with the HER. Calcareous deposits on the cathode surface could result in significant mass transport limitation for hydrogen evolution. Current switching (i.e., polarity) has been shown to remove calcareous deposits, although this would require anti-corrosion cathode material.

The WEC with or without a PV power source has the potential to meet the growing demand for on-site wastewater treatment coupled with water reuse and, in select cases, for alternative fuel production from water-splitting. A scaled-up WEC or PWEC should be easy to transport to various environments, including urbanized areas, peri-urban environments, and remote locations in the developing world that lack viable sanitation facilities to treat domestic black water. These systems may also be used for treatment of industrial wastewaters, landfill leachates, anaerobic sludge digester effluents, and reverse osmosis concentrates.

\section{Acknowledgements}

The authors would like to acknowledge the financial support of the Bill and Melinda Gates Foundation (BMGF RTTC Grant OPP1037491 \& BMGF RTTC Grant OPP109500C) and the Korea Institute of Science and Technology for support provided for the graduate study of Kangwoo Cho. This project benefited from the use of instrumentation made available by the Caltech Environmental Analysis Center.

\section{Notes and references}

1 C. J. Vorosmarty, P. B. McIntyre, M. O. Gessner, D. Dudgeon, A. Prusevich, P. Green, S. Glidden, S. E. Bunn, C. A. Sullivan, C. R. Liermann and P. M. Davies, Nature, 2010, 467, 555-561.

2 S. B. Grant, J. D. Saphores, D. L. Feldman, A. J. Hamilton, T. D. Fletcher, P. L. M. Cook, M. Stewardson, B. F. Sanders, L. A. Levin, R. F. Ambrose, A. Deletic, R. Brown, S. C. Jiang, D. Rosso, W. J. Cooper and I. Marusic, Science, 2012, 337, 681-686.

3 USEPA, Guidelines for water reuse, Report EPA/600/R-12/618, US Environmental Protection Agency, Washington, D.C., 2012.

4 C. A. Martinez-Huitle and S. Ferro, Chem. Soc. Rev., 2006, 35, 1324-1340.

5 S. Trasatti, Electrochim. Acta, 1984, 29, 1503-1512.

6 M. Panizza and G. Cerisola, Chem. Rev., 2009, 109, 65416569.

7 H. Park, C. D. Vecitis and M. R. Hoffmann, J. Phys. Chem. C, 2009, 113, 7935-7945.

8 G. R. P. Malpass, D. W. Miwa, D. A. Mortari, S. A. S. Machado and A. J. Motheo, Water Res., 2007, 41, 2969-2977.

9 L. C. Chiang, J. E. Chang and T. C. Wen, Water Res., 1995, 29, 671-678.

10 C. R. Costa and P. Olivi, Electrochim. Acta, 2009, 54, 20462052.

11 G. R. P. Malpass, D. W. Miwa, S. A. S. Machado, P. Olivi and A. J. Motheo, J. Hazard. Mater., 2006, 137, 565-572.

12 D. W. Miwa, G. R. P. Malpass, S. A. S. Machado and A. J. Motheo, Water Res., 2006, 40, 3281-3289.

13 D. Rajkumar and K. Palanivelu, Ind. Eng. Chem. Res., 2003, 42, 1833-1839. 
14 D. Rajkumar and J. G. Kim, J. Hazard. Mater., 2006, 136, 203212.

15 H. Park, C. D. Vecitis and M. R. Hoffmann, J. Phys. Chem. A, 2008, 112, 7616-7626.

16 J. Choi, Y. Qu and M. R. Hoffmann, J. Nanopart. Res., 2012, 14, 983.

17 D. Valero, J. M. Ortiz, E. Exposito, V. Montiel and A. Aldaz, Environ. Sci. Technol., 2010, 44, 5182-5187.

18 H. Park, A. Bak, Y. Y. Ahn, J. Choi and M. R. Hoffmannn, J. Hazard. Mater., 2012, 211, 47-54.

19 H. Park, K. Choo, H. Park, J. Choi and M. R. Hoffmann, Chem. Eng. J., 2013, 215-216, 802-810.

20 M. G. Walter, E. L. Warren, J. R. McKone, S. W. Boettcher, Q. X. Mi, E. A. Santori and N. S. Lewis, Chem. Rev., 2010, 110, 6446-6473.

21 M. Panizza and G. Cerisola, Environ. Sci. Technol., 2004, 38, 5470-5475.

22 M. Panizza, M. Delucchi and G. Cerisola, J. Appl. Electrochem., 2005, 35, 357-361.

23 C. Comninellis, Electrochim. Acta, 1994, 39, 1857-1862.

24 S. Trasatti, Electrochim. Acta, 1987, 32, 369-382.

25 L. I. Krishtalik, Electrochim. Acta, 1981, 26, 329-337.

26 T. P. Gujar, V. R. Shinde, C. D. Lokhande and S. H. Han, J. Power Sources, 2006, 161, 1479-1485.

27 P. Shuk, H. D. Wiemhofer, U. Guth, W. Gopel and M. Greenblatt, Solid State Ionics, 1996, 89, 179-196.

28 O. Scialdone, S. Randazzo, A. Galia and G. Silvestri, Water Res., 2009, 43, 2260-2272.

29 Oleh Weres, US Pat., 7494583 B2, 2009.

30 USEPA, Onsite Wastewater Treatment Systems Manual, Report EPA/625/R-00/008, US Environmental Protection Agency, Washington, D.C., 2002.

31 O. H. Lowry, N. J. Rosebrough, A. L. Farr and R. J. Randall, J. Biol. Chem., 1951, 193, 265-275.

32 M. Dubois, K. A. Gilles, J. K. Hamilton, P. A. Rebers and F. Smith, Anal. Chem., 1956, 28, 350-356.

33 N. Mohan and N. Balasubramanian, J. Hazard. Mater., 2006, 136, 239-243.

34 L. Szpyrkowicz, G. H. Kelsall, S. N. Kaul and M. De Favei, Chem. Eng. Sci., 2001, 56, 1579-1586.

35 Y. Wang, Y. Wang, Y. L. Meng, H. M. Ding, Y. K. Shan, X. Zhao and X. Z. Tang, J. Phys. Chem. C, 2008, 112, 6620-6626.

36 M. R. Goncalves, I. P. Marques and J. P. Correia, Water Res., 2012, 46, 4217-4225.

37 J. M. Kesselman, O. Weres, N. S. Lewis and M. R. Hoffmann, J. Phys. Chem. B, 1997, 101, 2637-2643.
38 M. H. P. Santana and L. A. De Faria, Electrochim. Acta, 2006, 51, 3578-3585.

39 M. Panizza and G. Cerisola, Water Res., 2006, 40, 11791184.

40 Y. J. Jung, K. W. Baek, B. S. Oh and J. W. Kang, Water Res., 2010, 44, 5345-5355.

41 A. M. Polcaro, A. Vacca, M. Mascia, S. Palmas and J. R. Ruiz, J. Appl. Electrochem., 2009, 39, 2083-2092.

42 L. R. Czarnetzki and L. J. J. Janssen, J. Appl. Electrochem., 1992, 22, 315-324.

43 M. E. H. Bergmann, J. Rollin and T. Iourtchouk, Electrochim. Acta, 2009, 54, 2102-2107.

44 A. Kraft, M. Stadelmann, M. Blaschke, D. Kreysig, B. Sandt, F. Schroder and J. Rennau, J. Appl. Electrochem., 1999, 29, 861-868.

45 L. Szpyrkowicz, M. Radaelli and S. Daniele, Catal. Today, 2005, 100, 425-429.

46 L. Szpyrkowicz, S. N. Kaul, R. N. Neti and S. Satyanarayan, Water Res., 2005, 39, 1601-1613.

47 L. Szpyrkowicz, S. N. Kaul and R. N. Neti, J. Appl. Electrochem., 2005, 35, 381-390.

48 E. R. Blatchley and M. M. Cheng, Environ. Sci. Technol., 2010, 44, 8529-8534.

49 A. Kapalka, A. Katsaounis, N. L. Michels, A. Leonidova, S. Souentie, C. Comninellis and K. M. Udert, Electrochem. Commun., 2010, 12, 1203-1205.

50 G. Peez, J. Saiz, R. Ibanez, A. M. Urtiaga and I. Ortiz, Water Res., 2012, 46, 2579-2590.

51 A. Fernandes, M. J. Pacheco, L. Ciriaco and A. Lopes, J. Hazard. Mater., 2012, 199, 82-87.

52 M. Deborde and U. von Gunten, Water Res., 2008, 42, 13-51.

53 A. Vlyssides, E. M. Barampouti, S. Mai, D. Arapoglou and

A. Kotronarou, Environ. Sci. Technol., 2004, 38, 6125-6131.

54 P. Canizares, R. Paz, J. Lobato, C. Saez and M. A. Rodrigo, J. Hazard. Mater., 2006, 138, 173-181.

55 X. H. Lei and T. Maekawa, Bioresour. Technol., 2007, 98, 3521-3525.

56 F. Bonfatti, S. Ferro, F. Lavezzo, M. Malacarne, G. Lodi and A. De Battisti, J. Electrochem. Soc., 2000, 147, 592-596.

57 N. Mohan, N. Balasubramanian and C. A. Basha, J. Hazard. Mater., 2007, 147, 644-651.

58 USDOE, Energy Demands on Water Resources: Report to Congress on the Interdependency of Energy and Water, US Department of Energy, Washington D.C., 2006.

59 M. Li, C. P. Feng, Z. Y. Zhang, Z. L. Shen and N. Sugiura, Electrochem. Commun., 2009, 11, 1853-1856. 